\title{
Total Synthesis of the Chlorinated Marine Natural Product Dysamide B
}

\author{
Amanda C. Durow, G. Cliona Long, Susan J. O’Connell and Christine L. Willis ${ }^{\star \dagger}$ \\ ${ }^{\dagger}$ School of Chemistry, University of Bristol, Cantock's Close, Bristol, BS8 ITS, UK \\ Chris.Willis@bristol.ac.uk
}

SUPPORTING INFORMATION

\section{General Experimental Details}

All commercially available compounds were used without further purification except where stated. All moisture or air sensitive reactions were carried out in oven-dried glassware under a positive pressure of nitrogen using standard syringe/septa techniques. Anhydrous solvents were obtained by passing through a modified Grubbs system of alumina columns, manufactured by Anhydrous Engineering. Petroleum ether is of the $40-60{ }^{\circ} \mathrm{C}$ boiling point range. Routine monitoring of reactions was performed using precoated Merck-Keiselgel $60 \mathrm{~F}_{254}$ aluminium backed TLC plates. The spots were visualised by $\mathrm{UV}_{254}$ light, or potassium permanganate. Flash column chromatography ${ }^{1}$ was performed using silica gel (obtained from Fluorochem Ltd.) as the adsorbent.

Melting points were determined on an electrothermal apparatus and are uncorrected. Optical rotations were recorded using with the sodium $D$ line $(\lambda=589 \mathrm{~nm})$ on a Bellingham and Stanley ADP220 polarimeter and the $[\alpha]_{D}$ values are quoted in units $10^{-1} \mathrm{deg} \mathrm{cm}^{2} \mathrm{~g}^{-1}$. Infrared spectra were recorded on a Perkin Elmer Spectrum One FT-IR spectrometer in the solid or liquid state. ${ }^{1} \mathrm{H}$ and ${ }^{13} \mathrm{C}$ NMR spectra were recorded at using either a Jeol Delta/GX $400 \mathrm{MHz}$ or a Jeol Eclipse $400 \mathrm{MHz}$ spectrometer. The chemical shifts $(\delta)$ are reported in parts per million $(\mathrm{ppm})$ and the coupling constants $(\mathcal{J})$ are in Hertz $(\mathrm{Hz})$. Tetramethylsilane was used as the internal reference for proton and carbon chemical shifts. DEPT 135, COSY, HBQC and HMBC NMR spectra were routinely used to definitively assign the signals of ${ }^{1} \mathrm{H}$ and ${ }^{13} \mathrm{C}$ NMR spectra. Electron impact (EI) and chemical ionisation (Cl) mass spectra were recorded on a VG Analytical Autospec mass spectrometer. Electrospray (ESI) mass spectra were recorded on a Micromass LCT mass spectrometer or a VG Quattro mass spectrometer. Methane was the ionisation gas used for chemical ionisation. 


\section{Experimental Procedures}

\section{(2S,4S)-2-tert-Butoxycarbonylamino-4-methylpentane-1,5-dioic acid 1-tertbutyl 5-allyl diester 7}

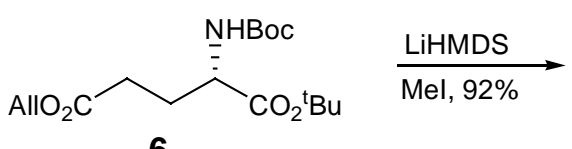

6

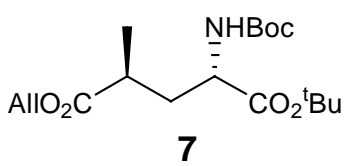

$n$-Butyl lithium (2.5 eq, $34.5 \mathrm{mmol}, 13.8 \mathrm{ml}$ ) was added dropwise to hexamethyldisilazane $(2.5 \mathrm{eq}, 34.5 \mathrm{mmol}$, $7.23 \mathrm{ml})$ in deoxygenated THF $(80 \mathrm{ml})$ at $0{ }^{\circ} \mathrm{C}$. The reaction mixture was stirred at $0{ }^{\circ} \mathrm{C}$ for $0.5 \mathrm{~h}$ before cooling to $-78{ }^{\circ} \mathrm{C}$. Diester $6(4.75 \mathrm{~g}, 13.8 \mathrm{mmol})$ in THF $(80 \mathrm{ml})$ was added dropwise and the reaction mixture was stirred at $-78{ }^{\circ} \mathrm{C}$ for $0.5 \mathrm{~h}$ before adding $\mathrm{Mel}(1.3 \mathrm{eq}, 17.94 \mathrm{mmol}, 1.13 \mathrm{ml})$. The reaction was monitored by TLC and after $4.5 \mathrm{~h}$ had reached completion. The reaction mixture was quenched with $\mathrm{HCl}(10 \%, 50 \mathrm{ml})$ and the aqueous layer extracted with DCM $(3 \times 70 \mathrm{ml})$. The combined organic layers were washed with water $(2 \times 30$ $\mathrm{ml}$ ), dried over anhydrous magnesium sulfate, filtered and the solvent removed in vacuo. Purification by column chromatography (10-15\% EtOAc/petrol) gave the alkylated diester 7 as a yellow oil $(4.56 \mathrm{~g}, 92 \%) ;[\alpha]_{D}-7.2$ (c 1.04, EtOH); $\delta_{\mathrm{H}}(400 \mathrm{MHz}) 1.25\left(3 \mathrm{H}, \mathrm{d}, J \mathrm{~J}, \mathrm{CH}_{3}\right), 1.43$ and 1.48 (each $\left.9 \mathrm{H}, \mathrm{s}, \mathrm{C}\left(\mathrm{CH}_{3}\right)_{3}\right), 1.85(1 \mathrm{H}, \mathrm{m}, 3-\mathrm{HH}), 1.98$ $(1 \mathrm{H}$, ddd, J 14, 10, 7, 3-HH), $2.58(1 \mathrm{H}, \mathrm{m}, 4-\mathrm{H}), 4.21(1 \mathrm{H}, \mathrm{m}, 2-\mathrm{H}), 4.56$ and 4.61 (each $1 \mathrm{H}$, each dd, J 13, 6, 1'$\left.\mathrm{H}_{2}\right), 4.9(1 \mathrm{H}, \mathrm{br} d, J$ 8, N-H), $5.24(1 \mathrm{H}, \mathrm{dd}, J$ 10, 2, 3'-HH), $5.32(1 \mathrm{H}, \mathrm{dd}, J$ 17, 2, 3'-HH), 5.91 (1H, ddt, J 17, 10, 6, 2'-H); $\delta_{\mathrm{C}}(75 \mathrm{MHz}) 17.2\left(\mathrm{CH}_{3}\right), 28$ and $28.3\left(\mathrm{C}\left(\mathrm{CH}_{3}\right)_{3}\right), 36.2(\mathrm{C}-3), 36.6(\mathrm{C}-4), 52.6(\mathrm{C}-2), 65.3(\mathrm{C}-1$ '), 81.9 and 82.4 (Cq), 118.2 (C-3'), 132.2 (C-2'), 153.3, 171.7 and 175.6 (CO); $v_{\max } / \mathrm{cm}^{-1} 3320,2979,1731,1706$ and 1645; $\mathrm{m} / \mathrm{z}(\mathrm{Cl}) 358\left(\mathrm{MH}^{+}, 2 \%\right), 202\left(\mathrm{MH}^{+}-\mathrm{Boc}-{ }^{\mathrm{t}} \mathrm{Bu}+1,100\right), 156(40)$ and 98 (15); Found $\mathrm{C} 60.44, \mathrm{H} 9.09$ and $\mathrm{N}$ 3.94, $\mathrm{C}_{18} \mathrm{~N}_{31} \mathrm{NO}_{6}$ requires $\mathrm{C} 60.59, \mathrm{H} 8.72$ and $\mathrm{N} 3.91$.

(2S,4S)-2-Ditert-butoxycarbonylamino-4-methylpentane-1,5-dioic acid 5-allyl ester 1-tertbutyl ester 8
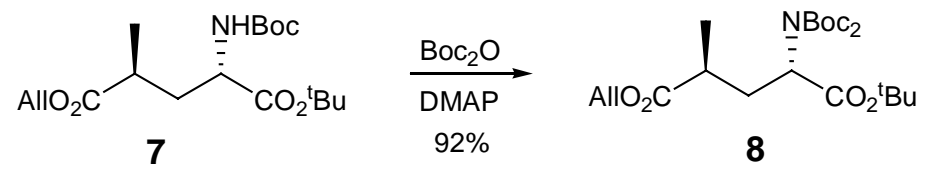

Allyl ester 7 (4.5 g, $12.6 \mathrm{mmol})$ was dissolved in MeCN (180 ml) and cooled to $0{ }^{\circ} \mathrm{C}$. Di-tert-butyldicarbonate (3 eq, $37,8 \mathrm{mmol}, 8.2 \mathrm{~g})$ in MeCN $(10 \mathrm{ml})$ was added followed by DMAP $(0.2 \mathrm{eq}, 2.52 \mathrm{mmol}, 0.3 \mathrm{~g})$ and the reaction mixture stirred at $0{ }^{\circ} \mathrm{C}$ for $2 \mathrm{~h}$ before warming to r.t and stirring overnight. After 2 days, further di-tertbutyldicarbonate (1.5 eq) and DMAP (0.2 eq) were added and the reaction mixture stirred for a further day. After this time the reaction had reached completion by TLC and the solvent was removed in vacuo. Purification by column chromatography (20\% EtOAc/petrol) gave the diboc protected diester 8 as an orange oil (5.31 g, 92\%); $[\alpha]_{\mathrm{D}}-10.5\left(\mathrm{c} 1, \mathrm{CHCl}_{3}\right) ; \delta_{\mathrm{H}}(400 \mathrm{MHz}) 1.21\left(3 \mathrm{H}, \mathrm{d}, J \mathrm{~J}, \mathrm{CH}_{3}\right), 1.44\left(9 \mathrm{H}, \mathrm{s}, \mathrm{C}\left(\mathrm{CH}_{3}\right)_{3}\right), 1.50\left(18 \mathrm{H}, \mathrm{s}, 2 \times \mathrm{C}\left(\mathrm{CH}_{3}\right)_{3}\right)$, $2.12\left(1 \mathrm{H}\right.$, ddd J 14, 8, 5, 3-HH), $2.32\left(1 \mathrm{H}\right.$, ddd, J 14, 10, 4, 3-HH), $2.55(1 \mathrm{H}, \mathrm{m}, 4-\mathrm{H}), 4.57\left(2 \mathrm{H}, \mathrm{m}, 1^{\prime}-\mathrm{H}_{2}\right), 4.81$ 


\section{Supporting Information}

$\left(1 \mathrm{H}, \mathrm{dd}, J\right.$ 10, 5, 2-H), $5.21\left(1 \mathrm{H}, \mathrm{dd}, J\right.$ 10, 1, 3'-HH), $5.29\left(1 \mathrm{H}, \mathrm{dd}, J 17,1,3{ }^{\prime}-\mathrm{HH}\right), 5.91(1 \mathrm{H}, \mathrm{ddt}, J$ 17, 10, 6,

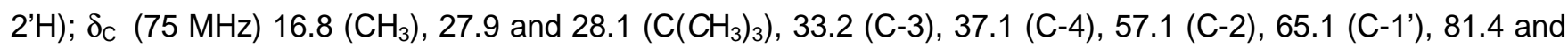
82.9 (Cq), 117.9 (C-3'), 132.5 (C-2'), 152.3, 169.6 and 175.7 (CO); $v_{\max } / \mathrm{cm}^{-1}$ 2979, 2937, 1735, 1701 and 1653; $\mathrm{m} / \mathrm{z}$ (EI) $356\left(\mathrm{M}^{+}-\mathrm{Boc}-1,34 \%\right), 256$ (10), 200 (30) and 156 (80); Found C 60.71, H 8.89 and N 3.17, $\mathrm{C}_{23} \mathrm{H}_{39} \mathrm{NO}_{8}$ requires $\mathrm{C} 60.37, \mathrm{H} 8.59$ and $\mathrm{N} 3.06$.

\section{(2S,4S)-2-Ditert-butoxycarbonylamino-4-methylpentane-1,5-dioic acid 1-tertbutyl ester 9}
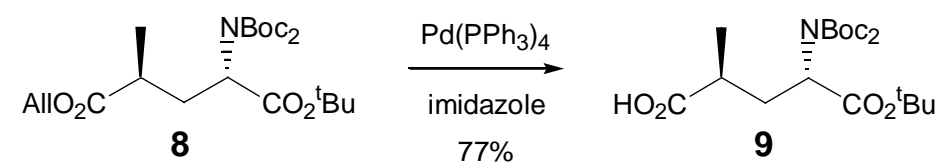

$\mathrm{Pd}\left(\mathrm{PPh}_{3}\right)_{4}(0.02 \mathrm{eq}, 0.143 \mathrm{~g}, 0.129 \mathrm{~g})$ was added to diester $8(2.85 \mathrm{~g}, 6.43 \mathrm{mmol})$ in THF (40 ml). After 5 minutes $\mathrm{NaBH}_{4}(1.5 \mathrm{eq}, 9.64 \mathrm{mmol}, 0.365 \mathrm{~g})$ was added and the reaction mixture was left overnight. The reaction was quenched with $\mathrm{HCl}(10 \%)$ and the aqueous layer extracted with $\mathrm{Et}_{2} \mathrm{O}(3 \times 50 \mathrm{ml})$. The combined organic layers were washed with water $(2 \times 15 \mathrm{ml})$ and brine $(15 \mathrm{ml})$, dried over anhydrous magnesium sulfate, filtered and the solvent removed in vacuo. Purification by column chromatography (10-20\% EtOAc/petrol) gave acid 9 as a yellow solid $(2.08 \mathrm{~g}, 77 \%)$ m.p 93-95 ${ }^{\circ} \mathrm{C} ;[\alpha]_{\mathrm{D}}-5.6\left(c 1.08, \mathrm{CHCl}_{3}\right) ; \delta_{\mathrm{H}}(400 \mathrm{MHz}) 1.23(3 \mathrm{H}, \mathrm{d}, \mathrm{J} 7$, $\left.\mathrm{CH}_{3}\right), 1.44\left(9 \mathrm{H}, \mathrm{s}, \mathrm{C}\left(\mathrm{CH}_{3}\right)_{3}\right), 1.5\left(18 \mathrm{H}, \mathrm{s}, \mathrm{C}\left(\mathrm{CH}_{3}\right)_{3}\right), 2.13(1 \mathrm{H}, \mathrm{ddd}, J 14,8,5,3-\mathrm{HH}), 2.36(1 \mathrm{H}$, ddd, J 14, 10, 6, 3-HH), $2.51(1 \mathrm{H}, \mathrm{m}, 4-\mathrm{H}), 4.83(1 \mathrm{H}, \mathrm{dd}, \mathrm{J} 10,5,2-\mathrm{H}) . \delta_{\mathrm{C}}(75 \mathrm{MHz}) 16.8\left(\mathrm{CH}_{3}\right), 27.9$ and $28.02\left(\mathrm{C}_{(}\left(\mathrm{CH}_{3}\right)_{3}\right), 32.9$ (C-3), 37 (C-4), 57.2 (C-2), 81.5 and $82.9(\mathrm{Cq}), 152.3,169.5$ and $175.5(\mathrm{CO}) ; v_{\mathrm{max}} / \mathrm{cm}^{-1} 3080,2979,1759$ and 1736; m/z (Cl) $362\left(\mathrm{MH}^{+}-{ }^{\mathrm{t}} \mathrm{Bu}, 3 \%\right), 262$ (15), 216 (10), 162 (23) and 57 (100); Found C 57.54, H 8.45, N 3.35, $\mathrm{C}_{20} \mathrm{H}_{35} \mathrm{O}_{8} \mathrm{~N}$ requires $\mathrm{C} 57.62, \mathrm{H} 8.57$, N 3.35.

\section{(2S,4S)-2-Ditertbutoxycarbonylamino-5-hydroxy-4-methyl-pentanoic acid tertbutyl ester $10^{2}$}

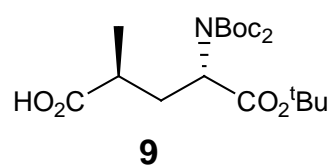

9

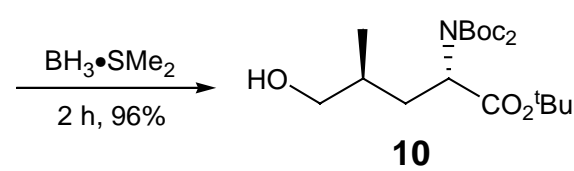

10

$\mathrm{BMS} \mathrm{SMe}_{2}$ (1 eq, $4.98 \mathrm{mmol}, 2 \mathrm{M}$ sol. in THF, $2.49 \mathrm{ml}$ ) was added dropwise to acid 9 (2.08 $\left.\mathrm{g}, 4.98 \mathrm{mmol}\right)$ in $\mathrm{Et}_{2} \mathrm{O}(15 \mathrm{ml})$. After $2 \mathrm{~h}$ the reaction had reached completion by TLC. The solvent was removed in vacuo and the crude product purified by column chromatography (20\% EtOAc/petrol) to yield alcohol $\mathbf{1 0}$ as a colourless oil (1.92 g, 96\%). m.p. $55-58{ }^{\circ} \mathrm{C} ;[\alpha]_{\mathrm{D}}-28.2\left(c 2.1, \mathrm{CHCl}_{3}\right) ; \delta_{\mathrm{H}}(400 \mathrm{MHz}) 0.95\left(3 \mathrm{H}, \mathrm{d}, J 7, \mathrm{CH}_{3}\right), 1.44(9 \mathrm{H}, \mathrm{s}$, $\left.\mathrm{C}\left(\mathrm{CH}_{3}\right)_{3}\right), 1.5\left(18 \mathrm{H}, \mathrm{s}, 2 \times \mathrm{C}\left(\mathrm{CH}_{3}\right)_{3}\right), 1.7(1 \mathrm{H}, \mathrm{m}, 4-\mathrm{H}), 1.93(1 \mathrm{H}, \mathrm{m}, 3-\mathrm{HH}), 1.95(1 \mathrm{H}, \mathrm{ddd}, \mathrm{J} 13,9,5,3-\mathrm{HH}), 3.44$ $(1 \mathrm{H}, \mathrm{dd}, J 11,5,5-H \mathrm{H}), 3.48(1 \mathrm{H}, \mathrm{dd}, J 11,7,5-\mathrm{H} H), 4.83(1 \mathrm{H}, \mathrm{dd}, J 9,6,2-\mathrm{H}) ; \delta_{\mathrm{C}}(75 \mathrm{MHz}) 16.2\left(\mathrm{CH}_{3}\right), 28$ and

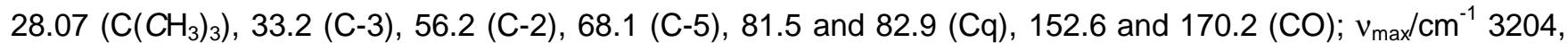
2978, 2935, 1785 and 1737; m/z (Cl) $348\left(\mathrm{M}^{+}-{ }^{\mathrm{t}} \mathrm{Bu}, 2 \%\right), 304(3), 248$ (5), 148 (40) and 57 (100); Found C 59.65, $\mathrm{H} 9.67$, and $\mathrm{N} 3.32, \mathrm{C}_{20} \mathrm{H}_{37} \mathrm{O}_{7} \mathrm{~N}$ requires $\mathrm{C} 59.53, \mathrm{H} 9.24, \mathrm{~N} 3.47$. 


\section{Supporting Information}

(Data not previously reported ${ }^{2}$ )

\section{(2S,4S)-2-Ditertbutoxycarbonylamino-4-methyl-5-oxopentanoic tertbutyl ester $11^{3}$}

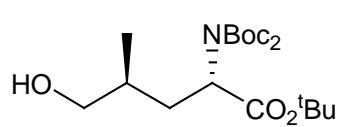

10

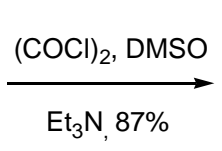

$\mathrm{Et}_{3} \mathrm{~N}, 87 \%$

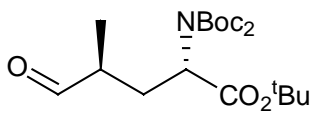

11

Oxalyl chloride (2 eq, $20.27 \mathrm{mmol}, 1.77 \mathrm{ml}$ ) in DCM (20 ml) was added slowly to DMSO (4 eq, $40.54 \mathrm{mmol}, 2.87$ $\mathrm{ml})$ in DCM $(70 \mathrm{ml})$ at $-78^{\circ} \mathrm{C}$, followed by the dropwise addition of alcohol 10 (4.09 g, $\left.10.14 \mathrm{mmol}\right)$ in DCM (20 $\mathrm{ml}$ ). After $45 \mathrm{mins} \mathrm{Et}_{3} \mathrm{~N}$ (8 eq, $81.09 \mathrm{mmol}, 11.3 \mathrm{ml}$ ) was added and the temperature increased to $-45^{\circ} \mathrm{C}$. After stirring at this temperature for $1 \mathrm{~h} 45$ mins aqueous $\mathrm{NH}_{4} \mathrm{Cl}(30 \mathrm{ml})$ was added. The aqueous layer was extracted with DCM (3 $\times 40 \mathrm{ml})$, the combined organic layers were washed with water $(2 \times 20 \mathrm{ml})$ and brine $(20 \mathrm{ml})$, dried over anhydrous magnesium sulfate and the solvent removed in vacuo. Purification by column chromatography (20\% EtOAc/petrol) gave aldehyde 11 as a yellow oily solid (3.55 g, 87\%); m.p. $56-58{ }^{\circ} \mathrm{C}$ (previously reported as an oil $\left.{ }^{3}\right) ;[\alpha]_{D}-25\left(c 2, \mathrm{CHCl}_{3}\right) ; \delta_{\mathrm{H}}(400 \mathrm{MHz}) 1.15\left(3 \mathrm{H}, \mathrm{d}, J \mathrm{~J}, \mathrm{CH}_{3}\right), 1.45\left(9 \mathrm{H}, \mathrm{s}, \mathrm{C}\left(\mathrm{CH}_{3}\right)_{3}\right), 1.51(18 \mathrm{H}, \mathrm{s}, 2 \mathrm{x}$ $\left.\mathrm{C}\left(\mathrm{CH}_{3}\right)_{3}\right), 1.97(1 \mathrm{H}$, ddd, $J 16,11,6,3-H \mathrm{H}), 2.34-2.44(2 \mathrm{H}, \mathrm{m}, 3-\mathrm{HH}$ and 4-H), $4.82(1 \mathrm{H}, \mathrm{dd}, J 11,5,2-\mathrm{H}), 9.6$

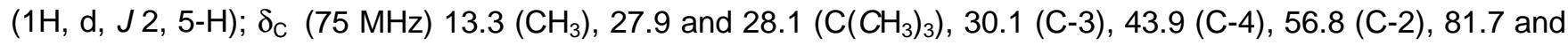
$83.14(\mathrm{Cq}), 152.5,170$ and $203.8(\mathrm{CO}) ; v_{\max } / \mathrm{cm}^{-1} 2978,2936,1735$ and 1697; $\mathrm{m} / \mathrm{z}(\mathrm{Cl}) 402\left(\mathrm{MH}^{+}, 16 \%\right), 346$ (58), 302 (8) and 128 (100); Found C 60.09, H 8.47, N 3.25, $\mathrm{C}_{20} \mathrm{H}_{35} \mathrm{O}_{7} \mathrm{~N}$, requires C 59.81, H 8.79, N 3.49.

\section{(2S,4S)-2-Ditertbutoxycarbonylamino-4-methylhex-5-enoic acid tertbutyl ester 12}

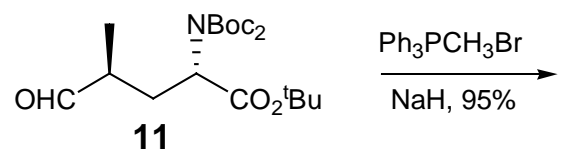

11

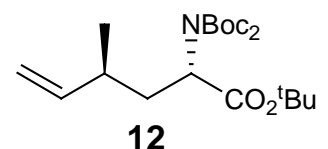

12

Sodium hydride (12 eq, $74.8 \mathrm{mmol}, 2.9 \mathrm{~g}$ ) was added to $\mathrm{MePh}_{3} \mathrm{PBr}(12 \mathrm{eq}, 74.8,26.7 \mathrm{~g}$ ) in THF (80 ml) and the mixture warmed slightly with a heat gun until a green tinge persisted. The reaction mixture was left stirring overnight before allowing to stand and adding to the dry aldehyde 11 ( $2.5 \mathrm{~g}, 6.23 \mathrm{mmol})$. After stirring overnight the reaction had reached completion. The solvent was removed in vacuo and the crude material was purified by column chromatography (5-20\% EtOAc/petrol) to give alkene 12 as a pale yellow oil $(2.37 \mathrm{~g}, 95 \%) ;[\alpha]_{\mathrm{D}}-10.2$ (c 1, $\left.\mathrm{CHCl}_{3}\right) ; \delta_{\mathrm{H}}(400 \mathrm{MHz}) 1.02\left(3 \mathrm{H}, \mathrm{d}, J \mathrm{~J}, \mathrm{CH}_{3}\right), 1.43\left(9 \mathrm{H}, \mathrm{s}, \mathrm{C}\left(\mathrm{CH}_{3}\right)_{3}\right), 1.52\left(18 \mathrm{H}, \mathrm{s}, \mathrm{C}\left(\mathrm{CH}_{3}\right)_{3}\right), 1.82(1 \mathrm{H}, \mathrm{ddd}, J$ 14, 8, 6, 3-HH), $2.04(1 \mathrm{H}$, ddd, J 14, 10, 6, 3-HH), $2.25(1 \mathrm{H}, \mathrm{m}, 4-\mathrm{H}), 4.79(1 \mathrm{H}, \mathrm{dd}, J$ 8, 6, 2-H), $4.92(1 \mathrm{H}, \mathrm{dd}, J$ 10, 1, 6-HH), $4.98(1 \mathrm{H}, \mathrm{dd}, J 17,1,6-\mathrm{HH}), 5.69\left(1 \mathrm{H}\right.$, ddd, J 17, 10, 7, 5-H); $\delta_{\mathrm{c}}(100 \mathrm{MHz}) 19.8\left(\mathrm{CH}_{3}\right), 28.02$ and $28.1\left(\mathrm{C}\left(\mathrm{CH}_{3}\right)_{3}\right), 35.2(\mathrm{C}-4), 36.2(\mathrm{C}-3), 57.5(\mathrm{C}-2), 81$ and $82.4(\mathrm{Cq}), 112.7(\mathrm{C}-6), 144(\mathrm{C}-5), 152.4$ and 170 (CO); $v_{\max } / \mathrm{cm}^{-1}$ 2978, 1760, 1735, 1701 and 1641; $\mathrm{m} / \mathrm{z}(\mathrm{Cl}) 400\left(\mathrm{MH}^{+}, 20 \%\right), 300(15), 344(100), 288(75)$ and 188 (77); Found C 63.56, H 9.85, N 3.31, $\mathrm{C}_{21} \mathrm{H}_{37} \mathrm{NO}_{6}$ requires C 63.31, H 9.33, N 3.51. 


\section{(2S,4S)-2-Ditertbutoxycarbonylamino-6-hydroxy- 4-methylhexanoic acid tertbutyl ester 13}

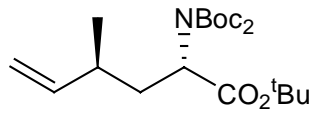

12

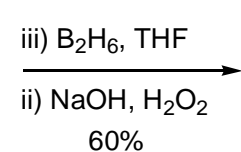

$60 \%$

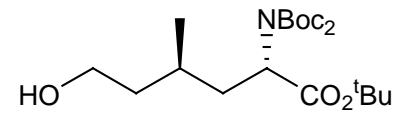

13

Borane - THF complex (1.3 eq, $1 \mathrm{M}$ sol. in THF, $7.6 \mathrm{mmol}, 7.6 \mathrm{ml}$ ) was added to alkene 12 (2.34 g, $5.86 \mathrm{mmol})$ in THF $(30 \mathrm{ml})$ at $0{ }^{\circ} \mathrm{C}$ before allowing to warm to room temperature. The reaction was monitored by TLC and after $4.5 \mathrm{~h}$ had reached completion. Aqueous $\mathrm{NaOH}(1.5 \mathrm{eq}, 8.79 \mathrm{mmol}, 8.79 \mathrm{ml})$ and $\mathrm{H}_{2} \mathrm{O}_{2}(35 \%, 11 \mathrm{eq}, 64.4$ $\mathrm{mmol}, 7.3 \mathrm{ml}$ ) were added and the mixture stirred for $0.5 \mathrm{~h}$. After this time, brine $(5 \mathrm{ml})$ and water $(10 \mathrm{ml})$ were added. The aqueous layer was extracted with EtOAc $(3 \times 60 \mathrm{ml})$. The combined organic layers were washed with water $(2 \times 20 \mathrm{ml})$, dried over anhydrous magnesium sulfate, filtered and the solvent removed in vacuo. Purification by column chromatography gave the alcohol 13 as a white solid $(1.44 \mathrm{~g}, 60 \%)$. m.p $45-47^{\circ} \mathrm{C} ;[\alpha]_{D}-$ 32.4 (c 1.9, $\left.\mathrm{CHCl}_{3}\right) ; \delta_{\mathrm{H}}(400 \mathrm{MHz}) 0.89\left(3 \mathrm{H}, \mathrm{d}, \mathrm{J} 6, \mathrm{CH}_{3}\right), 1.36\left(9 \mathrm{H}, \mathrm{s}, \mathrm{C}\left(\mathrm{CH}_{3}\right)_{3}\right), 1.44\left(18 \mathrm{H}, \mathrm{s}, \mathrm{C}\left(\mathrm{CH}_{3}\right)_{3}\right), 1.56-1.7$ $\left(3 \mathrm{H}, \mathrm{m}, 5-\mathrm{H}_{2}, 4-\mathrm{H}\right), 1.77$ (1H, ddd, J 14, 10, 5, 3-HH), 2.0 (1H, ddd, J 14, 10, 4, 3-HH), 3.66 (2H, ddd, J 17, 10,

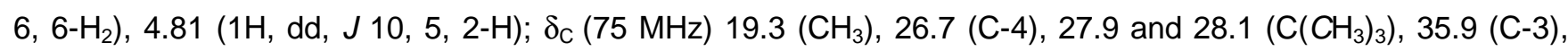
40.3 (C-5), 57.1 (C-2), 60.9 (C-6), 81.2 and 82.7 (Cq), 152.7 and 170 (CO); $v_{\max } / \mathrm{cm}^{-1} 3457,2978,2934,1736$ and 1699; $\mathrm{m} / \mathrm{z}(\mathrm{Cl}) 262\left(\mathrm{M}^{+}-\mathrm{Boc}-{ }^{\mathrm{t}} \mathrm{Bu}, 0.5 \%\right), 162$ (63) and 57 (100); Found: C 60.31, H 9.33, N 3.23, $\mathrm{C}_{21} \mathrm{H}_{39} \mathrm{NO}_{7}$ requires $\mathrm{C} 60.41, \mathrm{H} 9.41, \mathrm{~N} 3.35$.

\section{(2S,4S)-2-Ditertbutyloxycarbonylamino-4-methyl-6-oxohexanoic acid tertbutyl ester 14}

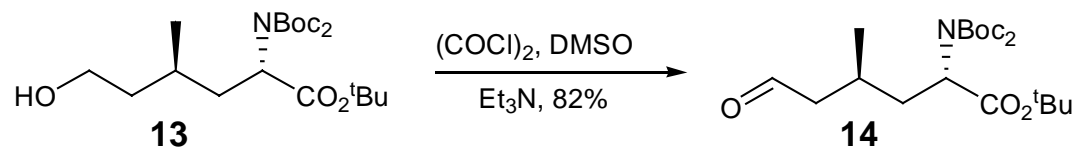

A solution of oxalyl chloride (2 eq, $9.77 \mathrm{mmol}, 0.85 \mathrm{ml})$ in DCM $(10 \mathrm{ml})$ was added dropwise to a solution of DMSO (4 eq, $19.6 \mathrm{mmol}, 1.39 \mathrm{ml})$ in DCM $(40 \mathrm{ml})$ at $-78{ }^{\circ} \mathrm{C}$ under $\mathrm{N}_{2}$. This was followed by the dropwise addition of the alcohol 13 (1 eq, $2.04 \mathrm{~g}, 4.89 \mathrm{mmol}$ ) in DCM. After 45 minutes $\mathrm{Et}_{3} \mathrm{~N}$ was added (8 eq, 39.12 $\mathrm{mmol}, 5.45 \mathrm{ml}$ ) and the temperature increased to $-45^{\circ} \mathrm{C}$. The reaction was monitored by TLC and after $4.5 \mathrm{~h}$ had reached completion. Saturated aqueous $\mathrm{NH}_{4} \mathrm{Cl}(30 \mathrm{ml})$ was added. The aqueous phase was extracted with $\operatorname{DCM}(3 \times 30 \mathrm{ml})$, the combined organic layers were washed with water $(20 \mathrm{ml})$ and brine $(20 \mathrm{ml})$, dried over anhydrous magnesium sulfate, filtered and the solvent removed in vacuo. Purification by column chromatography (20\% EtOAc/petrol) gave aldehyde 14 as a pale yellow solid (1.8 g, 82\%); m.p 49-52 ${ }^{\circ} \mathrm{C}$; $[\alpha]_{D}-$ 26.2 (c 1.2, $\left.\mathrm{CHCl}_{3}\right) ; \delta_{\mathrm{H}}(400 \mathrm{MHz}) 1.01\left(3 \mathrm{H}, \mathrm{d}, \mathrm{J}\right.$ 6, $\left.\mathrm{CH}_{3}\right), 1.44\left(9 \mathrm{H}, \mathrm{s}, \mathrm{C}\left(\mathrm{CH}_{3}\right)_{3}\right), 1.51\left(18 \mathrm{H}, \mathrm{s}, 2 \times \mathrm{C}\left(\mathrm{CH}_{3}\right)_{3}\right), 1.85$ - $2\left(2 \mathrm{H}, \mathrm{m}, 3-\mathrm{H}_{2}\right), 2.1(1 \mathrm{H}, \mathrm{m}, 4-\mathrm{H}), 2.3(1 \mathrm{H}, \mathrm{ddd}, J 17,8,2,5-\mathrm{HH}), 2.4(1 \mathrm{H}, \mathrm{ddd}, J 17,6,2,5-H \mathrm{H}), 4.8(1 \mathrm{H}, \mathrm{dd}, J$ 8, 6, 2-H), $9.7(1 \mathrm{H}, \mathrm{t}, \mathrm{J} 2,6-\mathrm{H}) ; \delta_{\mathrm{C}}(100 \mathrm{MHz}), 19.4\left(\mathrm{CH}_{3}\right), 25.5(\mathrm{C}-4), 28.0\left(3 \times \mathrm{C}\left(\mathrm{CH}_{3}\right)_{3}\right), 36.0(\mathrm{C}-3), 51.2(\mathrm{C}-5)$, 


\section{Supporting Information}

57 (C-2), 81.1 and $82.9(\mathrm{Cq}), 152.1,170$ and $211(\mathrm{CO}) ; v_{\max } / \mathrm{cm}^{-1}$ 2979, 1750 and 1730; $\mathrm{m} / \mathrm{z}(\mathrm{Cl}) 432\left(\mathrm{M}^{+}, 6 \%\right)$, 360 (11), 232 (14) and 57 (100); Found C 60.70, H 8.98, N 3.37, $\mathrm{C}_{21} \mathrm{H}_{37} \mathrm{NO}_{7}$ requires C 60.61, H 9.39, N 3.18.

\section{(2S,4S)-2-Ditertbutyloxycarbonylamino-5,5-dichloro-4-methyl-6-oxohexanoic acid tertbutyl ester} 15

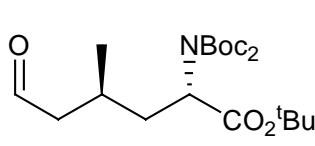

14

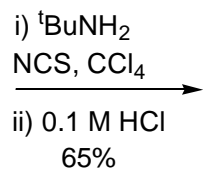

$65 \%$

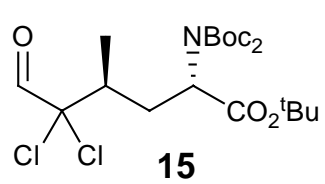

15

tert-Butyl amine ( 1 eq, $5.87 \mathrm{mmol}, 0.62 \mathrm{ml}$ ) was added to a rapidly stirring solution of the aldehyde 14 ( 1 eq, 2.44 $\mathrm{g}, 5.87 \mathrm{mmol})$ in $\mathrm{CCl}_{4}(20 \mathrm{ml})$ at room temperature under $\mathrm{N}_{2}$. The solution was stirred for $1 \mathrm{~h}$ in the presence of molecular sieves $(4 \AA)$ after which time further $\mathrm{CCl}_{4}(10 \mathrm{ml})$ and $\mathrm{MgSO}_{4}(5 \mathrm{~g})$ were added and the suspension filtered. $\mathrm{N}$-Chlorosuccinimide $(2.2 \mathrm{eq}, 12.9 \mathrm{mmol}, 1.73 \mathrm{~g})$ was added in one portion and the suspension was stirred overnight. The succinimide was removed by filtration and the filtrate evaporated in vacuo. The product was hydrolysed by stirring in $\mathrm{HCl}(0.1 \mathrm{M}, 53 \mathrm{ml})$ overnight. After this time $\mathrm{Et}_{2} \mathrm{O}(70 \mathrm{ml})$ was added to the reaction mixture and layers were separated. The aqueous layer was extracted with $\mathrm{Et}_{2} \mathrm{O}(3 \times 30 \mathrm{ml})$, the combined organic layers were washed with water $(2 \times 18 \mathrm{ml})$ dried over anhydrous magnesium sulfate and the solvent removed in vacuo to give the dichlorinated aldehyde 15 as yellow oil $(1.86 \mathrm{~g}, 65 \%) ;[\alpha]_{\mathrm{D}}-29.5\left(c 1.5, \mathrm{CHCl}_{3}\right) ; \delta_{\mathrm{H}}$ $(400 \mathrm{MHz}) 1.2\left(3 \mathrm{H}, \mathrm{d}, J \mathrm{~J}, \mathrm{CH}_{3}\right), 1.45\left(9 \mathrm{H}, \mathrm{s}, \mathrm{C}\left(\mathrm{CH}_{3}\right)_{3}\right), 1.52\left(18 \mathrm{H}, \mathrm{s}, 2 \times \mathrm{C}\left(\mathrm{CH}_{3}\right)_{3}\right), 2.0(1 \mathrm{H}, \mathrm{ddd}, J 15,11,4,3-$ $H \mathrm{H}), 2.38\left(2 \mathrm{H}, \mathrm{m}, 3-\mathrm{HH}\right.$ and 4-H), $4.80\left(1 \mathrm{H}, \mathrm{dd}, \mathrm{J}\right.$ 8, 4, 2-H), $9.21(1 \mathrm{H}, \mathrm{s}, 6-\mathrm{H}) ; \delta_{\mathrm{C}}(100 \mathrm{MHz}), 14.6\left(\mathrm{CH}_{3}\right), 27.9$ and $28\left(\mathrm{C}\left(\mathrm{CH}_{3}\right)_{3}\right), 31.1(\mathrm{C}-3), 39.5(\mathrm{C}-4), 56.6(\mathrm{C}-2), 81.7$ and $83(\mathrm{Cq}), 93.9(\mathrm{C}-5), 152.5(\mathrm{CO}), 169.3(\mathrm{CO}), 185$ (C-6); $v_{\text {max }} / \mathrm{cm}^{-1}$ 2976, 2930 and 1734; m/z (EI) 281 (1), 270 (2), 186 (3), 184 (13), 182 (21), 164 (7), 57 (100); $\mathrm{C}_{6} \mathrm{H}_{10} \mathrm{O}_{2} \mathrm{Cl}_{2} \mathrm{NO}^{+}$requires 182.0139 , found 182.0137

(2S,4S)-2-Ditertbutyloxycarbonylamino-5,5-dichloro-4-methylhexane-1,6-dioic acid 1-tertbutyl ester 16
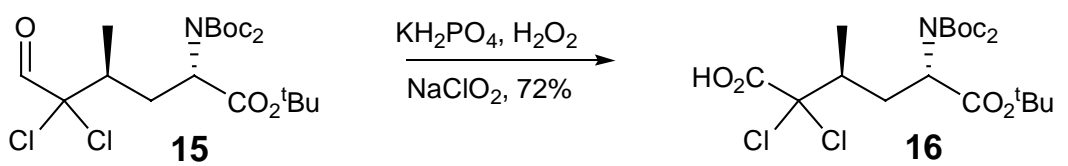

An aqueous $\mathrm{KH}_{2} \mathrm{PO}_{4}$ solution ( $\mathrm{pH} 4,0.4 \mathrm{ml}$ ) was added to dichlorinated aldehyde 15 ( $1 \mathrm{eq}, 0.226 \mathrm{~g}, 0.466 \mathrm{mmol}$ ) in $\mathrm{MeCN}(3 \mathrm{ml})$ at $0{ }^{\circ} \mathrm{C}$. This was followed by the addition of $\mathrm{H}_{2} \mathrm{O}_{2}(3.5 \mathrm{eq}, 30 \%, 1.6 \mathrm{mmol}, 0.047 \mathrm{ml})$ and $\mathrm{NaClO}_{2}$ (2.2 eq, $1.03 \mathrm{mmol}, 0.093 \mathrm{~g})$ in water $(4.5 \mathrm{ml})$. The reaction was monitored by TLC and after $2 \mathrm{~h}$ had reached completion. $\mathrm{Na}_{2} \mathrm{SO}_{3}(0.05 \mathrm{~g})$ was added to destroy any excess $\mathrm{NaClO}_{2}$ and the mixture was stirred for a further $1 \mathrm{~h}$. The reaction mixture was acidified to $\mathrm{pH} 3$ with $\mathrm{HCl}(10 \%, 1.3 \mathrm{ml})$. The aqueous phase was extracted with EtOAc $(3 \times 15 \mathrm{ml})$. The combined organic layers were washed with water $(2 \times 8 \mathrm{ml})$, dried over anhydrous magnesium sulfate and the solvent removed in vacuo to give acid 16 as a white solid $(0.168 \mathrm{~g}, 72 \%) .(0.14 \mathrm{~g}$, 


\section{Supporting Information}

56\%); m.p. 155-157 ${ }^{\circ} \mathrm{C}$; [a $]_{\mathrm{D}}-27.3\left(\mathrm{c} 1.2, \mathrm{CHCl}_{3}\right) ; \delta_{\mathrm{H}}(400 \mathrm{MHz}) 1.23\left(3 \mathrm{H}, \mathrm{d}, \mathrm{J}\right.$ 6, $\left.\mathrm{CH}_{3}\right), 1.45\left(9 \mathrm{H}, \mathrm{s}, \mathrm{C}\left(\mathrm{CH}_{3}\right)_{3}\right)$, $1.51\left(18 \mathrm{H}, \mathrm{s}, 2 \times \mathrm{C}\left(\mathrm{CH}_{3}\right)_{3}\right), 2.03(1 \mathrm{H}$, ddd, J 15, 11, 3, 3-HH), 2.35-2.45 (1H, m, 4-H), $2.53(1 \mathrm{H}, \mathrm{ddd}, J 15,7,3$, 3-HH), $4.83(1 \mathrm{H}, \mathrm{dd}, J 11,3,2-\mathrm{H}) ; \delta_{\mathrm{C}}(100 \mathrm{MHz}) 14.9\left(\mathrm{CH}_{3}\right), 28.0\left(\mathrm{C}_{\left.\left(\mathrm{CH}_{3}\right)_{3}\right),} 31.6(\mathrm{C}-3), 42.1(\mathrm{C}-4), 57.0(\mathrm{C}-2)\right.$, 82.0 and $83.8(\mathrm{Cq}), 113.6(\mathrm{C}-5), 152.3,169.0$ and $170.0(\mathrm{CO}) ; v_{\max } / \mathrm{cm}^{-1} 3150,2977,1780$ and 1726; $\mathrm{m} / \mathrm{z}(\mathrm{El})$ 402 (0.1) 400 (0.3), 398 (0.4), 302 (0.35), 300 (2.6), 298 (0.35), 202 (2), 200 (8), 202 (14); $\mathrm{C}_{11} \mathrm{H}_{18} \mathrm{Cl}_{2} \mathrm{NO}_{4}$ requires 298.0613 , found 298.0619 .

\section{(2S,4S)-2-Ditertbutyloxycarbonylamino-5,5-dichloro-4-methylpentanoic acid tertbutyl ester $17^{3}$}
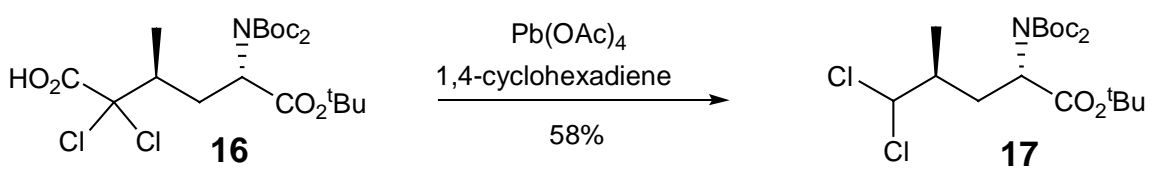

Lead tetraacetate ( $1 \mathrm{eq}, 1.10 \mathrm{mmol}, 0.486 \mathrm{~g}$ ) was added in one portion to acid 16 ( $1 \mathrm{eq}, 0.58 \mathrm{~g}, 1.10 \mathrm{mmol})$ in benzene $(15 \mathrm{ml})$ under $\mathrm{N}_{2}$. This was followed by the addition of 1,4-cyclohexadiene (1.2 eq, $\left.1.32 \mathrm{mmol}, 0.12 \mathrm{ml}\right)$ and the reaction heated under gentle refluxing conditions at $60{ }^{\circ} \mathrm{C}$ for $2 \mathrm{~h}$. Further $\mathrm{Pb}(\mathrm{OAc})_{4}(1 \mathrm{eq})$ and $1,4-$ cyclohexadiene (1.2 eq) were added and the reaction was heated under refluxing conditions for another $1 \mathrm{~h}$. The mixture was diluted with $\mathrm{Et}_{2} \mathrm{O}(20 \mathrm{ml})$ and washed with perchloric acid $(7 \%, 2 \times 15 \mathrm{ml})$. The aqueous layer was extracted with $\mathrm{Et}_{2} \mathrm{O}(3 \times 15 \mathrm{ml})$. The combined organic layers were washed with sat. aqueous $\mathrm{NaHCO}_{3}$ solution $(3 \times 10 \mathrm{ml})$. Again the aqueous layer was extracted with $\mathrm{Et}_{2} \mathrm{O}(1 \times 10 \mathrm{ml})$. The combined organic layers were washed with water $(2 \times 18 \mathrm{ml})$, dried over anhydrous magnesium sulfate, filtered and the solvent removed in vacuo. The crude material was purified by column chromatography ( $0-5 \% \mathrm{EtOAc/petrol)}$ to give dichlorinated protected amino acid 17 as a white solid (0.29 g, 58\%). The $\mathrm{NaHCO}_{3}$ extracts were acidified and extracted with ethyl acetate, dried and concentrated in vacuo however no starting acid was recovered; m.p. $54-56{ }^{\circ} \mathrm{C}$ (previously reported as an oil $\left.{ }^{3}\right) ;[\alpha]_{D}-23\left(c 1.1\right.$. in $\left.\mathrm{CH}_{2} \mathrm{Cl}_{2}\right)$, (lit. $\left.{ }^{3}-25.5\left(c 0.95, \mathrm{CH}_{2} \mathrm{Cl}_{2}\right)\right) ; \delta_{\mathrm{H}}(400 \mathrm{MHz}) 1.28(3 \mathrm{H}$, d, J 6, $\left.\mathrm{CH}_{3}\right), 1.45\left(9 \mathrm{H}, \mathrm{s}, \mathrm{C}\left(\mathrm{CH}_{3}\right)_{3}\right), 1.51\left(18 \mathrm{H}, \mathrm{s}, 2 \times \mathrm{C}\left(\mathrm{CH}_{3}\right)_{3}\right), 2.03(1 \mathrm{H}, \mathrm{ddd}, J 14,10,4,3-H \mathrm{H}), 2.13(1 \mathrm{H}, \mathrm{m}$, 4-H), $2.3\left(1 \mathrm{H}\right.$, ddd, J 14, 11, 3, 3-HH), $4.78(1 \mathrm{H}, \mathrm{dd}, J 11,4,2-\mathrm{H}), 5.78(1 \mathrm{H}, \mathrm{d}, J 3,5-\mathrm{H}) ; \delta_{\mathrm{C}}(100 \mathrm{MHz}), 15.0$

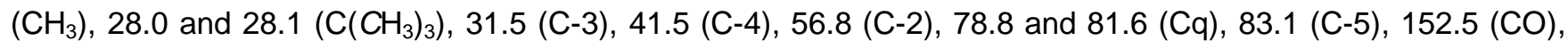
and $169.6(\mathrm{CO}) ; v_{\max } / \mathrm{cm}^{-1}$ 2980, 1735 and 1710; $\mathrm{m} / \mathrm{z}(\mathrm{Cl}) 456\left(\mathrm{MH}^{+}, 1 \%\right), 400$ (12), $344(30), 288(36)$, and 57 (100); Found C 52.84, H 7.73, N 2.83, Cl 15.39, $\mathrm{C}_{20} \mathrm{H}_{35} \mathrm{NO}_{6} \mathrm{C}_{12}$, requires C 52.63, H 7.56, N 3.07, Cl 15.54.

\section{(2S,4S)-2-Ditertbutyloxycarbonylamino-5,5-dichloro-4-methylpentanoic acid tertbutyl ester $17^{3}$}

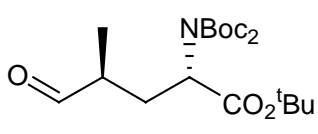

11

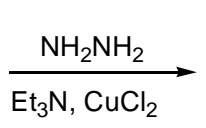

$45 \%$

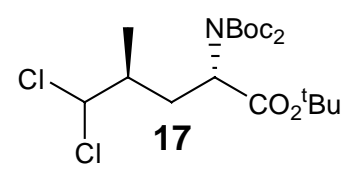

17

Aldehyde $11(3 \mathrm{~g}, 7.47 \mathrm{mmol})$ in $\mathrm{MeOH}(20 \mathrm{ml})$ was added dropwise to hydrazine hydrate (20 eq, $149 \mathrm{mmol}, 7.26$ $\mathrm{ml})$ in $\mathrm{MeOH}(20 \mathrm{ml})$. The reaction was stirred for $2 \mathrm{~h}$ before adding further hydrazine hydrate (10 eq) and 


\section{Supporting Information}

stirring for an additional $1 \mathrm{~h}$. The reaction mixture was concentrated in vacuo. Meanwhile $\mathrm{Et}_{3} \mathrm{~N}$ (3 eq, 22.42 mmol, $3.12 \mathrm{ml}$ ) was added to a solution of $\mathrm{CuCl}_{2}(6 \mathrm{eq}, 44.8 \mathrm{mmol}, 6.03 \mathrm{~g})$ in $\mathrm{MeOH}(30 \mathrm{ml})$ and stirred for 10 minutes. The crude hydrazone was added dropwise to the pre-stirred solution of $\mathrm{Et}_{3} \mathrm{~N}$ and $\mathrm{CuCl}_{2}$ and the reaction mixture stirred for $3 \mathrm{~h}$ before adding an aqueous solution of $\mathrm{NH}_{3}(3.5 \%, 30 \mathrm{ml})$. The reaction mixture was extracted with $\mathrm{Et}_{2} \mathrm{O}(3 \times 40 \mathrm{ml})$ and the combined organic layers were washed with water $(2 \times 20 \mathrm{ml})$ and brine $(20 \mathrm{ml})$ before drying over anhydrous magnesium sulfate and the solvent removed in vacuo. Purification by column chromatography (0-10\% EtOAc/petrol) gave the dichloride 17 as a white solid (1.54 g, 45\%). Spectral data as above.

(2S,4S)-5,5-Dichloroleucine $1^{3}$<smiles></smiles>
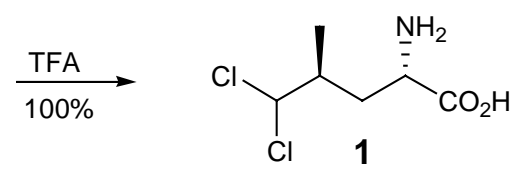

Dichloride 17 (2.7 g, $5.85 \mathrm{mmol})$ was dissolved in TFA (10 ml) and stirred for $1 \mathrm{~h}$. The mixture was concentrated in vacuo to give a white solid. Purification by Dowex column eluting with pyridine $(0.1 \mathrm{M})$ gave $2 S, 4 S$ dichloroleucine 1 as a white solid $(1.4 \mathrm{~g}, 100 \%)$; mp 222-223 ${ }^{\circ} \mathrm{C}$ (previously reported as an oil $\left.{ }^{3}\right)$; $[\alpha]_{\mathrm{D}}-38(c 1.0$, $\mathrm{H}_{2} \mathrm{O}$ ), (lit. ${ }^{3}-23(c 0.16, \mathrm{HCl} 1 \mathrm{~N})$ ); $\delta_{\mathrm{H}}\left(400 \mathrm{MHz}, \mathrm{D}_{2} \mathrm{O}\right) 1.20\left(3 \mathrm{H}, \mathrm{d}, J \mathrm{~J}, \mathrm{CH}_{3}\right), 2.01(1 \mathrm{H}, \mathrm{ddd}, J 15,10,5,3-H \mathrm{H})$, $2.16(1 \mathrm{H}, \mathrm{ddd}, J 15,9,4,3-\mathrm{HH}), 2.40(1 \mathrm{H}, \mathrm{m}, 4-\mathrm{H}), 3.92\left(1 \mathrm{H}, \mathrm{dd}, J\right.$ 9, 5, 2-H), $6.12(1 \mathrm{H}, \mathrm{d}, J 3,5-\mathrm{H}) ; \delta_{\mathrm{C}}(100$ $\mathrm{MHz} ; \mathrm{D}_{2} \mathrm{O}$ ), $17.0\left(\mathrm{CH}_{3}\right), 36.0$ (C-3), 42.6 (C-4), 57.1 (C-2), 81.5 (C-5), 177.4 (C-1); m/z (ESI) 204 (12), 202 (67), $200\left(\mathrm{MH}^{+}, 100 \%\right) ; \mathrm{C}_{6} \mathrm{H}_{12} \mathrm{O}_{2} \mathrm{NCl}_{2}$ requires 200.0240, found 200.0245 .

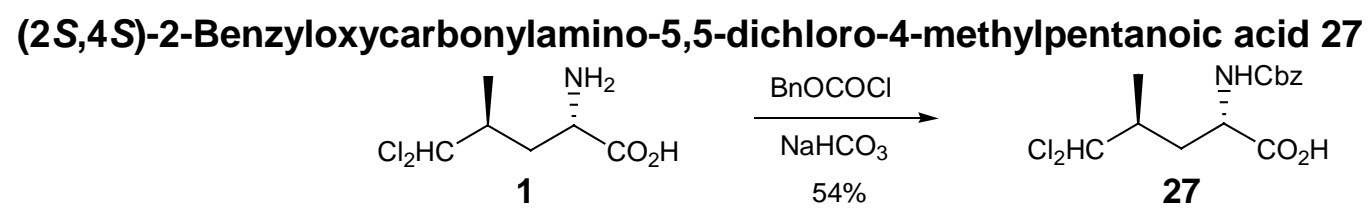

(2S, 4S)-Dichloroleucine 1 (5 g, $25.0 \mathrm{mmol})$ was dissolved in water $(95 \mathrm{ml})$ and dioxane $(39 \mathrm{ml})$ at $0{ }^{\circ} \mathrm{C}$. $\mathrm{NaHCO}_{3}$ (1 eq, $38.12 \mathrm{mmol}, 3.2 \mathrm{~g}$ ) was added followed by benzyl chloroformate $(1.1 \mathrm{eq}, 41.9 \mathrm{mmol}, 5.98 \mathrm{ml})$ in dioxane $(52 \mathrm{ml})$. The reaction mixture was stirred at $0{ }^{\circ} \mathrm{C}$ for $2 \mathrm{~h}$ then warmed to room temperature and stirred overnight. The reaction mixture was washed with $\mathrm{Et}_{2} \mathrm{O}(3 \times 30 \mathrm{ml})$ and the combined aqueous layers acidified to $\mathrm{pH} 2(\mathrm{HCl}$, $1 \mathrm{~N})$ and extracted with EtOAc $(3 \times 50 \mathrm{ml})$. The combined organic layers were dried over anhydrous magnesium sulfate, filtered and the solvent removed in vacuo to give Cbz dichloroleucine 27 as a colourless oil (8.35g, 54\%); $[\alpha]_{D}-8.8\left(c 1.4, \mathrm{CH}_{2} \mathrm{Cl}_{2}\right) ; \delta_{\mathrm{H}}\left(400 \mathrm{MHz}\right.$, major rotamer) $1.21\left(3 \mathrm{H}, \mathrm{d}, J 7, \mathrm{CH}_{3}\right), 1.8-2.0\left(2 \mathrm{H}, \mathrm{m}, 3-\mathrm{H}_{2}\right), 2.3(1 \mathrm{H}, \mathrm{m}$, 4-H), $4.47(1 \mathrm{H}, \mathrm{m}, 2-\mathrm{H}), 5.13\left(2 \mathrm{H}, \mathrm{br} \mathrm{s}, \mathrm{CH}_{2}\right), 5.78(1 \mathrm{H}, \mathrm{d}, J 3,5-\mathrm{H}), 7.2-7.4(5 \mathrm{H}, \mathrm{m}, \mathrm{Ph}-\mathrm{H}), 7.7(1 \mathrm{H}, \mathrm{br} \mathrm{s}$, $\left.\mathrm{CO}_{2} \mathrm{H}\right) ; \delta_{\mathrm{C}}(100 \mathrm{MHz}) 14.9\left(\mathrm{CH}_{3}\right), 35.07(\mathrm{C}-3), 40.8(\mathrm{C}-4), 51.78(\mathrm{C}-2), 67.5\left(\mathrm{CH}_{2}\right), 78.4(\mathrm{C}-5), 128.1-128.6(\mathrm{Ph})$, 
136 (ipso), 156.6 (C-1); $v_{\max } / \mathrm{cm}^{-1} 3314,2971,1694,1523$ and 1217; $\mathrm{m} / \mathrm{z}(\mathrm{Cl}) 334\left(\mathrm{MH}^{+}, 2 \%\right), 308$ (6), 226 (11), 218 (15) and 91 (100); $\mathrm{C}_{14} \mathrm{H}_{18} \mathrm{Cl}_{2} \mathrm{NO}_{4}$ requires 334.0607, found 334.0612.

(2S,4S)-2-(N-Benzyloxycarbonyl-N-methyl-amino)-5,5-dichloro-4-methylpentanoic acid 30<smiles>C[C@H](C=CCl)C[C@H](NC(=O)O)C(=O)O</smiles>

27

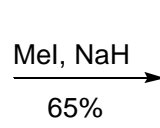

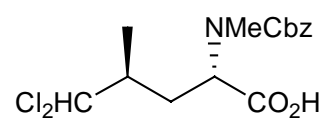

30

$\mathrm{N}$-Cbz dichlorinated leucine $27(0.43 \mathrm{~g}, 1.29 \mathrm{mmol})$ was dissolved in $\mathrm{MeCN}(10 \mathrm{ml})$ at $0{ }^{\circ} \mathrm{C}$. Mel $(8 \mathrm{eq}, 10.3$ mmol, $0.7 \mathrm{ml}$ ) was added followed by $\mathrm{NaH}(3.87 \mathrm{mmol} 0.15 \mathrm{~g}$ ) before allowing the reaction mixture to warm to room temperature and stirring for $24 \mathrm{~h}$. Ethyl acetate $(20 \mathrm{ml})$ was added followed by water $(5 \mathrm{ml})$ before removing the solvent in vacuo. The crude material was dissolved in $\mathrm{Et}_{2} \mathrm{O}(10 \mathrm{ml})$ and water $(10 \mathrm{ml})$ and the separated aqueous layer washed with $\mathrm{Et}_{2} \mathrm{O}(3 \times 10 \mathrm{ml})$. The combined organic layers were washed with a sat aqueous solution of $\mathrm{NaHCO}_{3}(2 \times 5 \mathrm{ml})$. The combined aqueous layers were acidified to $\mathrm{pH} 2 \mathrm{with} \mathrm{HCl}(1 \mathrm{M})$, extracted with EtOAc $(3 \times 10 \mathrm{ml})$, washed with water $(10 \mathrm{ml})$, sodium thiosulfate $(2 \times 5 \mathrm{ml})$ then further washed with water $(5 \mathrm{ml})$. The combined organic layers were dried over anhydrous magnesium sulfate and the solvent removed in vacuo. Purification by column chromatography (0-20\% EtOAc/petrol) gave $\mathrm{N}-\mathrm{Me}$ dichloride $\mathbf{3 0}$ as an oil $(0.29 \mathrm{~g}, 65 \%) ;[\alpha]_{\mathrm{D}}-8.5\left(c 0.94, \mathrm{CH}_{2} \mathrm{Cl}_{2}\right) ; \delta_{\mathrm{H}}\left(400 \mathrm{MHz}\right.$, major rotamer) $1.19\left(3 \mathrm{H}, \mathrm{d}, \mathrm{J} 6, \mathrm{CH}_{3}\right), 1.85-2.1(2 \mathrm{H}$, m, 3- $\left.\mathrm{H}_{2}\right), 2.25(1 \mathrm{H}, \mathrm{m}, 4-\mathrm{H}), 2.9\left(3 \mathrm{H}, \mathrm{s}, \mathrm{N}-\mathrm{CH}_{3}\right), 4.8(1 \mathrm{H}, \mathrm{dd}, \mathrm{J} 12,4,2-\mathrm{H}), 5.1-5.2\left(2 \mathrm{H}, \mathrm{m}, \mathrm{CH}_{2}\right), 5.8(1 \mathrm{H}, \mathrm{d}, \mathrm{J} 3$, 5-H), 7.3-7.4 (5H, m, Ph-H); $\delta_{\mathrm{C}}(100 \mathrm{MHz}) 15.4\left(\mathrm{CH}_{3}\right), 30.3(\mathrm{C}-3), 30.6\left(\mathrm{~N}_{-} \mathrm{CH}_{3}\right), 40.8(\mathrm{C}-4), 53.5(\mathrm{C}-2), 67.8$ $\left(\mathrm{CH}_{2}\right), 78.2$ (C-5), 1282-128.6 (Ph), 134 (ipso), 157.2 and $160(\mathrm{CO}) ; v_{\max } / \mathrm{cm}^{-1}$ 3150, 2926, 1719, 1705 and 1264; $\mathrm{m} / \mathrm{z}(\mathrm{Cl}) 348\left(\mathrm{MH}^{+}, 6 \%\right), 304$ (26), 268 (24) and 91 (100); $\mathrm{C}_{15} \mathrm{H}_{20} \mathrm{Cl}_{2} \mathrm{NO}_{4}$ requires 348.0765, found 348.0769 .

(2S,4S)-2-( $N$-Benzyloxycarbonyl- $N$-methylamino)-5,5-dichloro-4-methylpentanoic acid methyl ester 28<smiles>CC(=O)NC(CC(C)C(=O)O)CC(C)C(=O)O</smiles>

Methyl iodide $(0.44 \mathrm{ml}, 6.72 \mathrm{mmol})$ was added to a solution of $\mathrm{N}$-Cbz dichlorinated leucine $27(0.28 \mathrm{~g}, 0.84$ $\mathrm{mmol})$ in THF/DMF $(10: 1,2 \mathrm{ml})$ followed by the addition of $\mathrm{NaH}(0.1 \mathrm{~g}, 2.52 \mathrm{mmol})$. The reaction mixture was heated at reflux for $24 \mathrm{~h}$, before cooling to room temperature and removing the solvent in vacuo. The crude material was dissolved in $\mathrm{Et}_{2} \mathrm{O}(5 \mathrm{ml})$ and washed with water $(2 \times 5 \mathrm{ml})$, sodium thiosulfate $(2 \times 5 \mathrm{ml})$ and further water $(5 \mathrm{ml})$. The organic layers were dried over anhydrous magnesium sulfate, filtered and the solvent removed 


\section{Supporting Information}

in vacuo. Purification by column chromatography (20\% EtOAc/petrol) gave N-Me methyl ester 28 as an oil $(0.19$ g, 62\%); $[\alpha]_{D}-13.3\left(c 3.4, \mathrm{CH}_{2} \mathrm{Cl}_{2}\right) ; \delta_{\mathrm{H}}\left(400 \mathrm{MHz}\right.$, major rotamer) $1.18\left(3 \mathrm{H}, \mathrm{d}, \mathrm{J} 6, \mathrm{CH}_{3}\right), 1.8-2\left(2 \mathrm{H}, \mathrm{m}, 3-\mathrm{H}_{2}\right)$, $2.17(1 \mathrm{H}, \mathrm{m}, 4-\mathrm{H}), 2.8\left(3 \mathrm{H}, \mathrm{s}, \mathrm{N}-\mathrm{CH}_{3}\right), 3.7\left(3 \mathrm{H}, \mathrm{s}, \mathrm{O}-\mathrm{CH}_{3}\right), 4.74(1 \mathrm{H}, \mathrm{dd}, J 12,4,2-\mathrm{H}), 5.17\left(2 \mathrm{H}, \mathrm{d}, J 3, \mathrm{CH}_{2}\right)$, $5.78(1 \mathrm{H}, \mathrm{d}, \mathrm{J} 3,5-\mathrm{H}), 7.3-7.4(5 \mathrm{H}, \mathrm{m}, \mathrm{Ph}-\mathrm{H}) ; \delta_{\mathrm{C}}(100 \mathrm{MHz}) 15.3\left(\mathrm{CH}_{3}\right), 30.1(\mathrm{C}-3), 30.3\left(\mathrm{~N}-\mathrm{CH}_{3}\right), 40.9(\mathrm{C}-4)$, $52.4\left(\mathrm{O}-\mathrm{CH}_{3}\right), 56.2(\mathrm{C}-2), 67.7\left(\mathrm{CH}_{2}\right), 78.7(\mathrm{C}-5), 127.7$ - $128.6(\mathrm{Ph}), 136$ (ipso), 157 and $171(\mathrm{CO}) ; v_{\mathrm{max}} / \mathrm{cm}^{-1}$ 2953, 1742 and 1698; m/z (Cl) $362\left(\mathrm{MH}^{+}, 64 \%\right), 326$ (48), 318 (82), 258 (92) and 91 (100); $\mathrm{C}_{16} \mathrm{H}_{22} \mathrm{Cl}_{2} \mathrm{NO}_{4}$ requires 362.0928 , found 362.0925 .

(2S,4S)-2-Methylamino-5,5-dichloro-4-methylpentanoic acid methyl ester hydrobromide salt 29

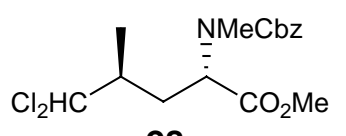

28

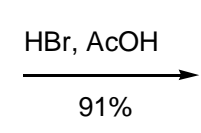

$91 \%$

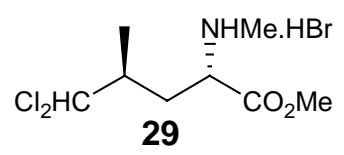

Hydrobromic acid $(37 \%, 1.5 \mathrm{ml})$ was added to $N$-methyl protected dichloroleucine 28 (0.206 g, $0.57 \mathrm{mmol})$ and stirred for $2 \mathrm{~h}$. The solvent was removed in vacuo and water $(10 \mathrm{ml})$ was added. The aqueous layer was washed with $\mathrm{Et}_{2} \mathrm{O}(2 \times 10 \mathrm{ml})$ before removing the solvent in vacuo to give the hydrobromide 29 as a yellow oil $(0.16 \mathrm{~g}$, 91\%); $[\alpha]_{\mathrm{D}}+8(c 1.5, \mathrm{MeOH}) ; \delta_{\mathrm{H}}\left(400 \mathrm{MHz}, \mathrm{D}_{2} \mathrm{O}\right) 1.12\left(3 \mathrm{H}, \mathrm{d}, J\right.$ 7, $\left.\mathrm{CH}_{3}\right), 1.95(1 \mathrm{H}, \mathrm{ddd}, J 15,7,4,3-H \mathrm{H}), 2.17$ $(1 \mathrm{H}$, ddd, J 15, 7, 5, 3- $\mathrm{HH}), 2.36(1 \mathrm{H}, \mathrm{m}, 4-\mathrm{H}), 2.68\left(3 \mathrm{H}, \mathrm{s}, \mathrm{N}-\mathrm{CH}_{3}\right), 3.7\left(3 \mathrm{H}, \mathrm{s}, \mathrm{O}-\mathrm{CH}_{3}\right), 4.12(1 \mathrm{H}, \mathrm{t}, J 7,2-\mathrm{H})$, $6.07(1 \mathrm{H}, \mathrm{d}, \mathrm{J} 3,5-\mathrm{H}) ; \delta_{\mathrm{C}}(100 \mathrm{MHz}) 15.1\left(\mathrm{CH}_{3}\right), 31.7(\mathrm{C}-3), 31.9\left(\mathrm{~N}^{-} \mathrm{CH}_{3}\right), 40.1(\mathrm{C}-4), 54.2\left(\mathrm{O}-\mathrm{CH}_{3}\right), 58.9(\mathrm{C}-2)$, 77.8 (C-5), 170 (C-1); $v_{\max } / \mathrm{cm}^{-1}$ 3353, 2948 and 1735; m/z (Cl) $228\left(\mathrm{MH}^{+}-\mathrm{HBr}, 92 \%\right), 192(84), 168$ (100), 156 (50) and 102 (89). $\mathrm{C}_{8} \mathrm{H}_{16} \mathrm{NO}_{2} \mathrm{Cl}_{2}$ requires 228.0558, found 228.0558.

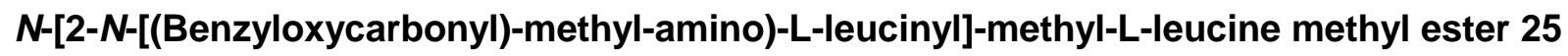

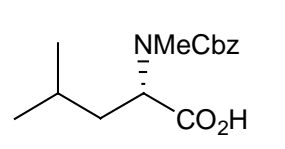

24

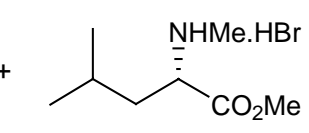

23

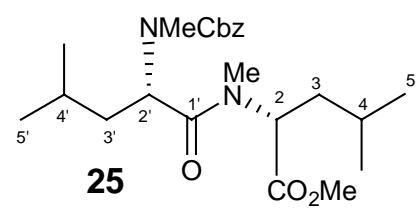

25

$\mathrm{CO}_{2} \mathrm{Me}$

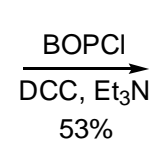

$53 \%$

$\mathrm{N}$-Methyl amino acid $24(0.35 \mathrm{~g}, 1.26 \mathrm{mmol})$ and hydrobromide salt 23 (1 eq, $1.26 \mathrm{mmol}, 0.302 \mathrm{~g})$ were dissolved in $\mathrm{DCM}(15 \mathrm{ml})$ at $0{ }^{\circ} \mathrm{C}$. $\mathrm{Et}_{3} \mathrm{~N}(2 \mathrm{eq}, 2.5 \mathrm{mmol}, 0.35 \mathrm{ml})$ and $\mathrm{BOPCl}(1.1 \mathrm{eq}, 1.38 \mathrm{~mol}, 0.35 \mathrm{~g})$ were then added and the reaction mixture stirred overnight. The reaction mixture was quenched with $\mathrm{HCl}(1 \mathrm{M}, 10 \mathrm{ml})$ and the aqueous layer extracted with EtOAc. The combined organic layers were washed with a sat aqueous solution of $\mathrm{NaHCO}_{3}(2 \times 8 \mathrm{ml})$ and water $(10 \mathrm{ml})$, dried over anhydrous magnesium sulfate, filtered and the solvent removed in vacuo. Purification by column chromatography (0-10\% EtOAc/petrol) gave dipeptide 25 as a white solid (0.28 g, 53\%). m.p. 103-105 ${ }^{\circ} \mathrm{C} ;[\alpha]_{\mathrm{D}}-132\left(c 1.3, \mathrm{CH}_{2} \mathrm{Cl}_{2}\right) ; \delta_{\mathrm{H}}(400 \mathrm{MHz}) 0.87$ and $0.92($ each $3 \mathrm{H}, \mathrm{d}$, 


\section{Supporting Information}

J 7, $\left.\mathrm{CH}_{3}\right), 0.95\left(6 \mathrm{H}, \mathrm{d}, J \mathrm{~J}, 2 \times \mathrm{CH}_{3}\right), 1.35-1.74\left(6 \mathrm{H}, \mathrm{m}, 2 \times 4-\mathrm{H}\right.$ and 3- $\left.\mathrm{H}_{2}\right), 2.84$ and 2.94 each $\left(3 \mathrm{H}, \mathrm{s}, \mathrm{N}-\mathrm{CH}_{3}\right)$, $3.69\left(3 \mathrm{H}, \mathrm{s}, \mathrm{O}-\mathrm{CH}_{3}\right), 5.12-5.25(2 \mathrm{H}, \mathrm{m}, 2 \times 2-\mathrm{H}), 5.35\left(2 \mathrm{H}, \mathrm{m}, \mathrm{CH}_{2}\right) ; \delta_{\mathrm{C}}(100 \mathrm{MHz}) 21.3$ and $22.4\left(\mathrm{CH}_{3}\right), 25(\mathrm{C}-4)$, 29.1 and $31.2\left(\mathrm{~N}^{-} \mathrm{CH}_{3}\right), 37.3(\mathrm{C}-3), 52.2\left(\mathrm{O}-\mathrm{CH}_{3}\right), 57.4(\mathrm{C}-2), 67.4\left(\mathrm{CH}_{2}\right)$, 127.7-128.6 (Ph), 136.2 (ipso), 156, 164 and 172.1 (CO); $v_{\text {max }} / \mathrm{cm}^{-1}$ 2956, 1742, 1695 and 1652; $\mathrm{m} / \mathrm{z}(\mathrm{Cl}) 421\left(\mathrm{MH}^{+}, 76 \%\right), 313$ (42), 262 (44), 234 (90) and 190 (100); Found $\mathrm{C} 65.53, \mathrm{H} 8.61$ and N 6.50, $\mathrm{C}_{23} \mathrm{H}_{36} \mathrm{~N}_{2} \mathrm{O}_{5}$ requires $\mathrm{C} 65.69, \mathrm{H} 8.63$ and N 6.66.

\section{$N$-[(2S,4S,2'S,4'S)-2-N-[(Benzyloxycarbonyl)-methyl-amino)-5,5,dichloroleucinyl]-methyl-5,5-} dichloroleucine methyl ester 31

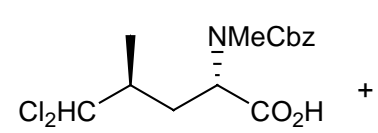

30<smiles>COC(=O)[C@H](C[C@H](C)C=O)NC(C)=O</smiles>

29

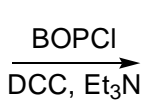

$54 \%$

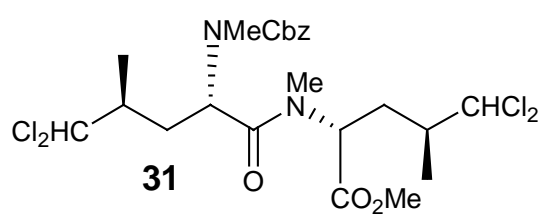

The above method was repeated with $\mathrm{N}$-methyl protected dichlorinated amino acid 30 ( 1 eq, $0.831 \mathrm{mmol}, 0.289$ g) and dichlorinated ester 29 (1 eq, $0.831 \mathrm{mmol}, 0.257 \mathrm{~g})$ to give dipeptide 31 as a colourless oil $(0.23 \mathrm{~g}, 54 \%)$; $[\alpha]_{\mathrm{D}}-42.2\left(c 1.8, \mathrm{CH}_{2} \mathrm{Cl}_{2}\right) ; \delta_{\mathrm{H}}(400 \mathrm{MHz}) 1.12$ and 1.18 (each $\left.3 \mathrm{H}, \mathrm{d}, J 6, \mathrm{CH}_{3}\right), 1.52-2.3(6 \mathrm{H}, \mathrm{m}, 2 \times 4-\mathrm{H}$ and 3$\left.\mathrm{H}_{2}\right), 2.8\left(6 \mathrm{H}, \mathrm{s}, 2 \times \mathrm{N}-\mathrm{CH}_{3}\right), 3.7\left(3 \mathrm{H}, \mathrm{s}, \mathrm{O}-\mathrm{CH}_{3}\right), 4.9-5.07(2 \mathrm{H}, \mathrm{m}, 2 \times 2-\mathrm{H}), 5.1$ and 5.19 each $\left(1 \mathrm{H}, \mathrm{d}, \mathrm{J} 9, \mathrm{CH}_{2}\right)$, 5.72 and 5.76 each $\left(1 \mathrm{H}, \mathrm{d}, J 3, \mathrm{CHCl}_{2}\right) ; \delta_{\mathrm{C}}(100 \mathrm{MHz}) 15.3\left(\mathrm{CH}_{3}\right), 29.7\left(\mathrm{~N}-\mathrm{CH}_{3}\right), 30.8(\mathrm{C}-3), 40.5(\mathrm{C}-4), 52.6(\mathrm{O}-$ $\mathrm{CH}_{3}$ ), $54.03(\mathrm{C}-2), 67.8\left(\mathrm{CH}_{2}\right), 78.6\left(\mathrm{CHCl}_{2}\right), 127.8-128.6(\mathrm{Ph}), 132$ (ipso), 156 and $171.3(\mathrm{CO}) ; v_{\max } / \mathrm{cm}^{-1} 2953$, 1741, 1694 and 1650; m/z (Cl) $557\left(\mathrm{MH}^{+}, 24 \%\right), 521(60), 302$ (70) and 258 (100). $\mathrm{C}_{23} \mathrm{H}_{33} \mathrm{Cl}_{2} \mathrm{~N}_{2} \mathrm{O}_{5}$ requires 557.1143 , found 557.1129 .

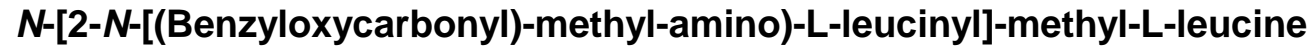

methyl

ester hydrobromic salt 26

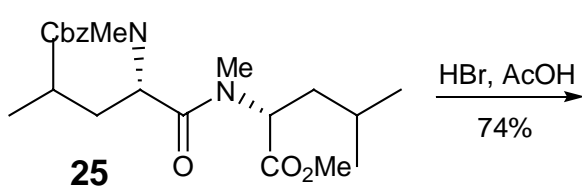<smiles>CN[C@H](CC(C)Br)C(=O)N[C@@H](CC(C)C)C(=O)O</smiles>

Dipeptide 25 (0.21 g, $0.499 \mathrm{mmol})$ was treated with $\mathrm{HBr}(37 \%, 5 \mathrm{ml})$ and stirred for $3 \mathrm{~h}$. The solvent was removed in vacuo and the crude material was dissolved in water and washed with $\mathrm{Et}_{2} \mathrm{O}(2 \times 10 \mathrm{ml})$. The solvent was removed in vacuo to give the hydrobromide salt 26 as an orange solid $(0.135 \mathrm{~g}, 74 \%) ;[\alpha]_{D}-36$ (c 1, $\mathrm{MeOH}) ; \delta_{\mathrm{H}}(400 \mathrm{MHz}) 0.82\left(3 \mathrm{H}, \mathrm{d}, J\right.$ 6, $\left.\mathrm{CH}_{3}\right), 0.84\left(3 \mathrm{H}, \mathrm{d}, J\right.$ 7, $\left.\mathrm{CH}_{3}\right), 0.93$ and $0.95\left(\right.$ each $3 \mathrm{H}, \mathrm{d}, J$ 7, $\left.2 \times \mathrm{CH}_{3}\right)$, 
1.42 - $1.44\left(1 \mathrm{H}, \mathrm{m}, \mathrm{CH}-\mathrm{CH}_{3}\right), 1.72-1.75\left(4 \mathrm{H}, \mathrm{m}, 2 \times \mathrm{CH}_{3}\right), 1.87-1.89\left(1 \mathrm{H}, \mathrm{m}, \mathrm{CH}-\mathrm{CH}_{3}\right), 2.6\left(3 \mathrm{H}, \mathrm{s}, \mathrm{N}-\mathrm{CH}_{3}\right), 3.05$ $\left(3 \mathrm{H}, \mathrm{s}, \mathrm{N}-\mathrm{CH}_{3}\right), 3.7\left(3 \mathrm{H}, \mathrm{s}, \mathrm{O}-\mathrm{CH}_{3}\right), 4.42\left(1 \mathrm{H}, \mathrm{t}, \mathrm{J}\right.$ 5, 2-H), $4.99(1 \mathrm{H}, \mathrm{dd}, J 11,5,2-\mathrm{H}) ; \delta_{\mathrm{C}}(100 \mathrm{MHz}) 20.09,22.09$, 23.9 and $24.5\left(\mathrm{CH}_{3}\right), 30.5$ and $31.8\left(\mathrm{~N}-\mathrm{CH}_{3}\right), 36.2\left(\mathrm{CH}_{2}\right), 38.6\left(\mathrm{CH}_{2}\right), 56\left(\mathrm{O}_{-} \mathrm{CH}_{3}\right), 58.1$ and $59(\mathrm{C}-2), 168.5$ and 172 (CO); $v_{\max } / \mathrm{cm}^{-1} 3327,2944,2831,1743$ and 1653; m/z (Cl) $288\left(\mathrm{MH}^{+}-\mathrm{HBr}, 100 \%\right), 230$ (10) and 101 (100); $\mathrm{C}_{15} \mathrm{H}_{31} \mathrm{BrN}_{2} \mathrm{O}_{3}$ requires 287.2329, found 287.2334.

\section{$N$-[(2S,4S,2'S,4'S)-2-N-[(Benzyloxycarbonyl)-methyl-amino)-5,5,dichloroleucinyl]-methyl-5,5-} dichloroleucine methyl ester hydrobromic salt 32

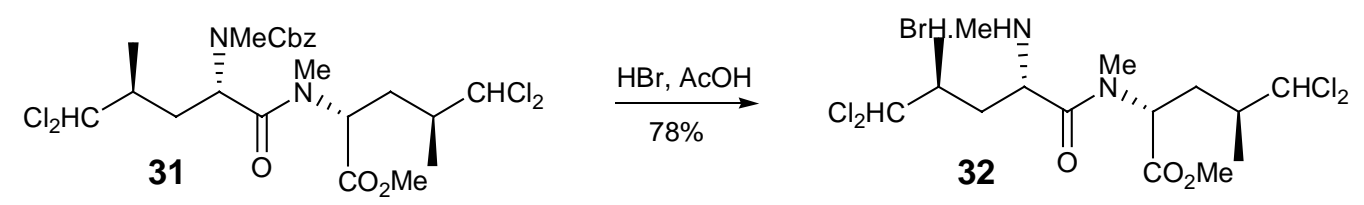

The above method was repeated using the chlorinated dipeptide $31(0.19 \mathrm{~g}, 0.34 \mathrm{mmol})$ to give the corresponding $\mathrm{HBr}$ salt 32 as an orange oil $(0.134 \mathrm{~g}, 78 \%) ;[\alpha]_{\mathrm{D}}-13.3(\mathrm{c} 1.2, \mathrm{MeOH}) ; \delta_{\mathrm{H}}(400 \mathrm{MHz}) 1.12$ and 1.23 (each $\left.3 \mathrm{H}, \mathrm{d}, \mathrm{J} 6, \mathrm{CH}_{3}\right), 1.8-2.3\left(6 \mathrm{H}, \mathrm{m}, 2 \times 4-\mathrm{H}\right.$ and $\left.3-\mathrm{H}_{2}\right), 2.7\left(3 \mathrm{H}, \mathrm{s}, \mathrm{N}-\mathrm{CH}_{3}\right), 3.07\left(3 \mathrm{H}, \mathrm{s}, \mathrm{N}-\mathrm{CH}_{3}\right), 3.7(3 \mathrm{H}$, s, O- $\left.\mathrm{CH}_{3}\right), 4.55\left(1 \mathrm{H}, \mathrm{dd}, J\right.$ 9, 4, 2-H), $5.09(1 \mathrm{H}, \mathrm{m}, 2-\mathrm{H}), 6.07\left(2 \mathrm{H}, \mathrm{d}, J 3,2 \times \mathrm{CHCl}_{2}\right) ; \delta_{\mathrm{C}}(100 \mathrm{MHz}) 15.04$ and $15.7\left(\mathrm{CH}_{3}\right), 32.5$ and $32.6\left(\mathrm{~N}-\mathrm{CH}_{3}\right), 35.5$ and $35.7\left(\mathrm{CH}_{2}\right), 40.1$ and $41.9(\mathrm{C}-4), 53.2\left(\mathrm{O}-\mathrm{CH}_{3}\right), 56.1$ and $58.3(\mathrm{C}-$ 2), 79.1 and $79.8\left(\mathrm{CHCl}_{2}\right), 170$ and $171.7(\mathrm{CO}) ; v_{\max } / \mathrm{cm}^{-1} 3355,2947,1739$ and 1655; $\mathrm{m} / \mathrm{z}(\mathrm{Cl}) 423\left(\mathrm{MH} \mathrm{H}^{+} \mathrm{HBr}\right.$, 20\%), 287 (44), 351 (38) and 168 (100); $\mathrm{C}_{15} \mathrm{H}_{27} \mathrm{~N}_{2} \mathrm{O}_{3} \mathrm{Cl}_{4}$ requires 423.0768, found 423.0775.

(3S,6S)-(2'-Methylpropyl)-1,4-dimethylpiperazine-2,5-dione 19

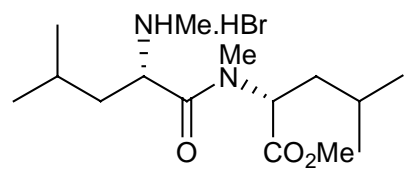

26
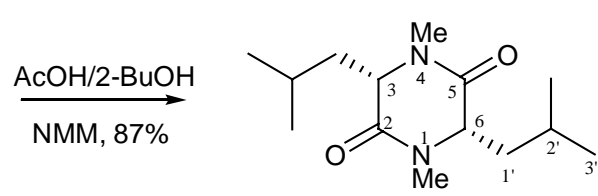

19

Dipeptide $26(0.1 \mathrm{~g}, 0.2722 \mathrm{mmol})$ was dissolved in acetic acid in 2-butanol $(2 \mathrm{M}, 10 \mathrm{ml})$, then treated with $\mathrm{N}$ methyl morpholine (2 eq, $0.544 \mathrm{mmol}, 0.06 \mathrm{ml}$ ) and heated at reflux for $4 \mathrm{~h}$. The solvent was removed in vacuo, the crude material dissolved in EtOAc $(15 \mathrm{ml})$, washed with water $(10 \mathrm{ml})$ and brine $(10 \mathrm{ml})$. The organic layers were dried over anhydrous magnesium sulfate, filtered and the solvent removed in vacuo. Purfication by column chromatography (0-25\% EtOAc/petrol) gave diketopiperazine 19 as a white solid (0.06 g, 87\%); m.p. $135-138{ }^{\circ} \mathrm{C}$ [lit. ${ }^{4}$ see below $\left.{ }^{\star}\right] ;\left[\alpha_{\mathrm{D}}\right]+32.2\left(c 1.0, \mathrm{CHCl}_{3}\right)\left[{ }^{2}{ }^{4}{ }^{4}+48.8\left(c 1.0, \mathrm{CHCl}_{3}\right)\right] ; \delta_{\mathrm{H}}(400 \mathrm{MHz}) 0.96$ and 0.98 (each $6 \mathrm{H}, \mathrm{d}$, $\left.J ~ 7,4 \times \mathrm{CH}_{3}\right), 1.57\left(2 \mathrm{H}\right.$, ddd, J 14, 9, 5, 1'- $\left.\mathrm{H}_{2}\right), 1.70\left(2 \mathrm{H}, \mathrm{ddd}, J 14,9,5,1^{\prime}-\mathrm{H}_{2}\right), 1.85-2.0(2 \mathrm{H}, \mathrm{m}, 2 \times 2$ '- $\mathrm{H}), 2.9$ $\left(6 \mathrm{H}, \mathrm{s}, 2 \times \mathrm{N}-\mathrm{CH}_{3}\right), 3.82(2 \mathrm{H}$, dd, J 9, 5, $2 \times 6-\mathrm{H}) ; \delta_{\mathrm{C}}(100 \mathrm{MHz}) 21.9$ and $23\left(\mathrm{CH}_{3}\right), 25.2(\mathrm{C}-2), 32.7\left(\mathrm{~N}-\mathrm{CH}_{3}\right)$, 43.7 (C-1'), 60.8 (C-3 and C-6) and 166.8 (CO); $v_{\max } / \mathrm{cm}^{-1}$ 2961, 1667, 1403; m/z (Cl) $255\left(\mathrm{MH}^{+}, 100\right)$; Found C 66.21, $\mathrm{H}, 10.37, \mathrm{~N} 11.05, \mathrm{C}_{14} \mathrm{H}_{26} \mathrm{~N}_{2} \mathrm{O}_{2}$ requires $\mathrm{C} 66.10, \mathrm{H} 10.30$ and $\mathrm{N} 11.01$. 


\section{Supporting Information}

${ }^{*} \mathrm{mp} .110{ }^{\circ} \mathrm{C}$ prepared using Mel/Ag $\mathrm{O} ; \mathrm{mp} .114-116{ }^{\circ} \mathrm{C}$ prepared using $\mathrm{Mel} / \mathrm{NaH}$ (Scheme 4$)^{4}$

\section{Dysamide B 3}
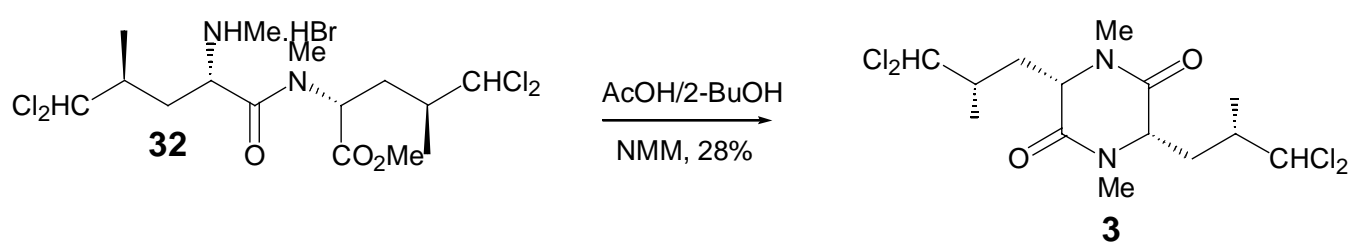

The above method was repeated with chlorinated dipeptide $32(0.113 \mathrm{~g}, 0.224 \mathrm{mmol})$ to give dysamide B 3 as a white solid (0.024 g, $28 \%$ ); m.p. $147-149{ }^{\circ} \mathrm{C}$ (lit. ${ }^{5}$ m.p -natural product $147-149{ }^{\circ} \mathrm{C}[\alpha]_{D}+10.7$ (c 1.6, MeOH) (lit. ${ }^{5}$ -natural product + $13.7(\mathrm{c} 0.117, \mathrm{MeOH})) ; \delta_{\mathrm{H}}(400 \mathrm{MHz}) 1.12\left(6 \mathrm{H}, \mathrm{d}, J\right.$ 6, $\left.\mathrm{CH}_{3}\right), 1.57(2 \mathrm{H}, \mathrm{ddd}, J$ 14, 10, 5, 1'$H \mathrm{H}), 2.19(2 \mathrm{H}, \mathrm{ddd}, J$ 14, 8, 5, 1'- $\mathrm{HH}), 2.49-2.51\left(2 \mathrm{H}, \mathrm{m}, 2 \times 22^{\prime}-\mathrm{H}\right), 2.94\left(6 \mathrm{H}, \mathrm{s}, 2 \times \mathrm{N}-\mathrm{CH}_{3}\right), 3.79(2 \mathrm{H}, \mathrm{dd}, J 10$, 5, 3-H and 6-H), $6.12\left(2 \mathrm{H}, \mathrm{d}, J 3,2 \times \mathrm{CHCl}_{2}\right) ; \delta_{\mathrm{C}}(100 \mathrm{MHz}) 15.6\left(\mathrm{C}-3^{\prime}\right), 33.03\left(\mathrm{~N}-\mathrm{CH}_{3}\right), 37.7\left(\mathrm{C}-1\right.$ '), $40.3\left(\mathrm{C}-2^{\prime}\right)$, 60.2 (C-3 and C-6), $77.4\left(\mathrm{CHCl}_{2}\right), 165.8(\mathrm{CO}) ; \mathrm{m} / \mathrm{z}(\mathrm{Cl}) 393\left(\mathrm{MH}^{+}, 78 \%\right), 355(100), 319(30)$ and $265(60)$; $\mathrm{C}_{14} \mathrm{H}_{23} \mathrm{Cl}_{4} \mathrm{~N}_{2} \mathrm{O}_{2}$ requires 391.0514 , found 391.0513 . 


\section{Supporting Information}

The ${ }^{1} \mathrm{H}$ - and ${ }^{13} \mathrm{C}$ NMR spectra of diketopiperazine 19 and dysamide $\mathrm{B} 3$ in $\mathrm{CDCl}_{3}$ are shown below:

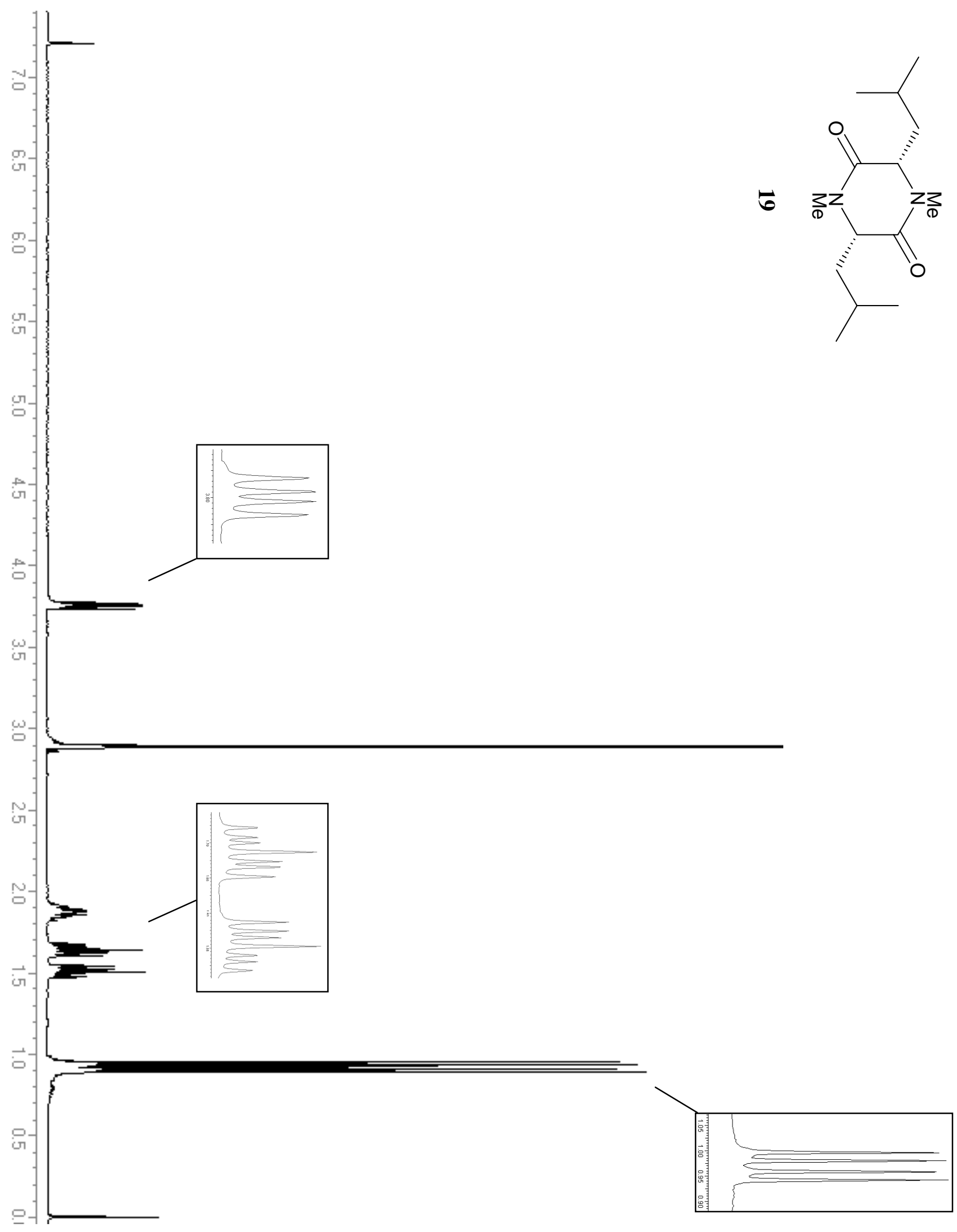


Supporting Information

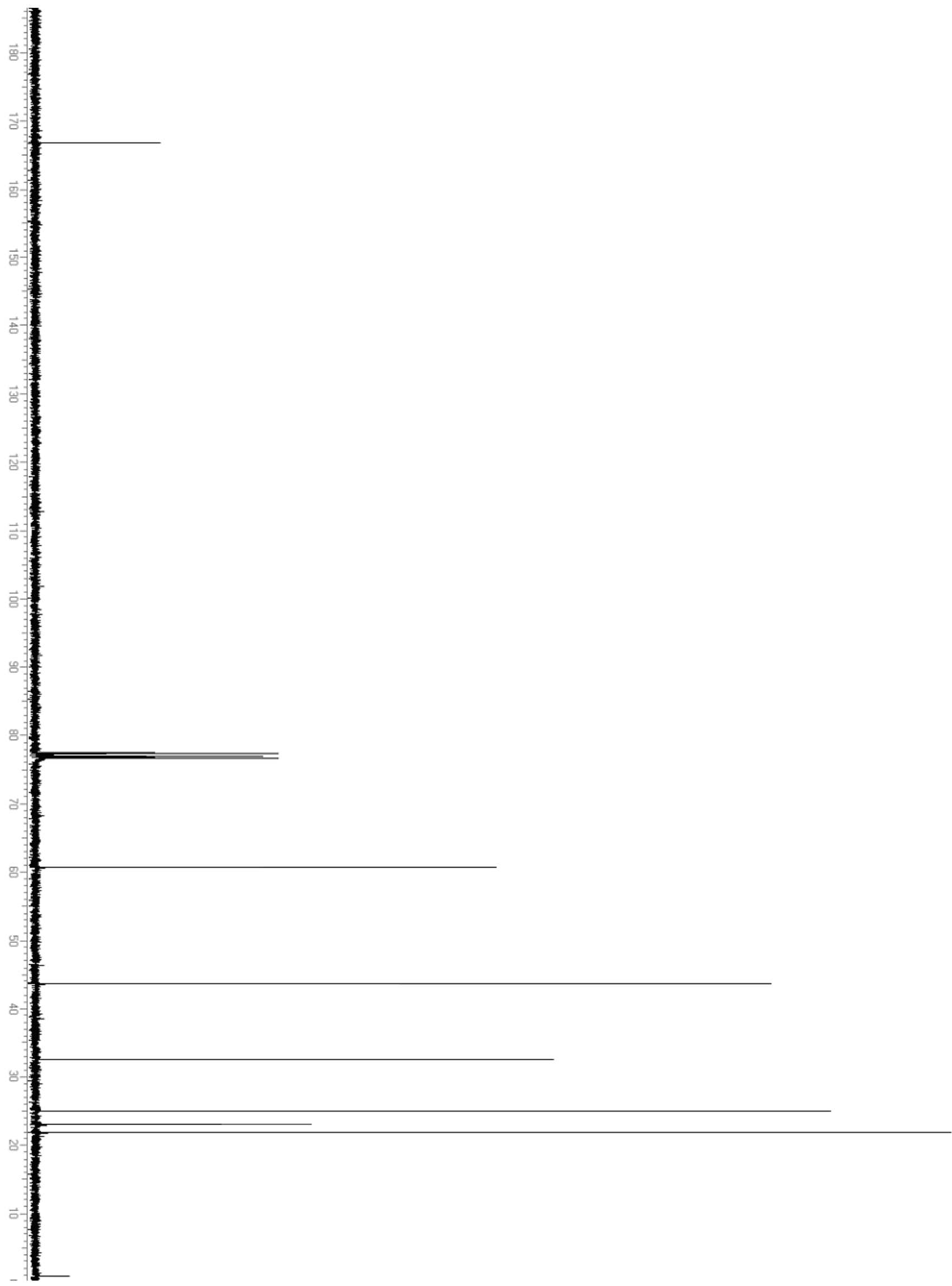




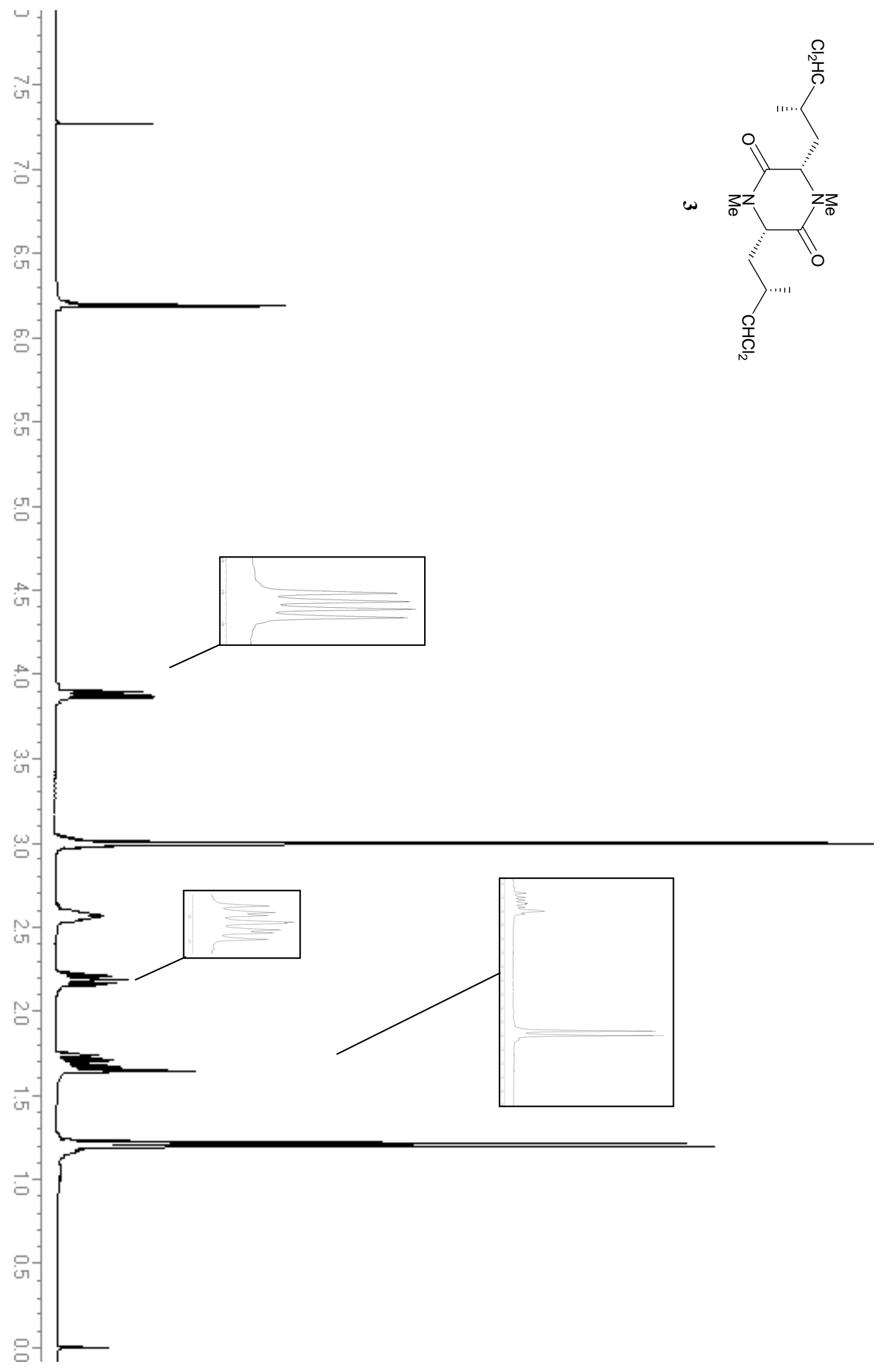


Supporting Information

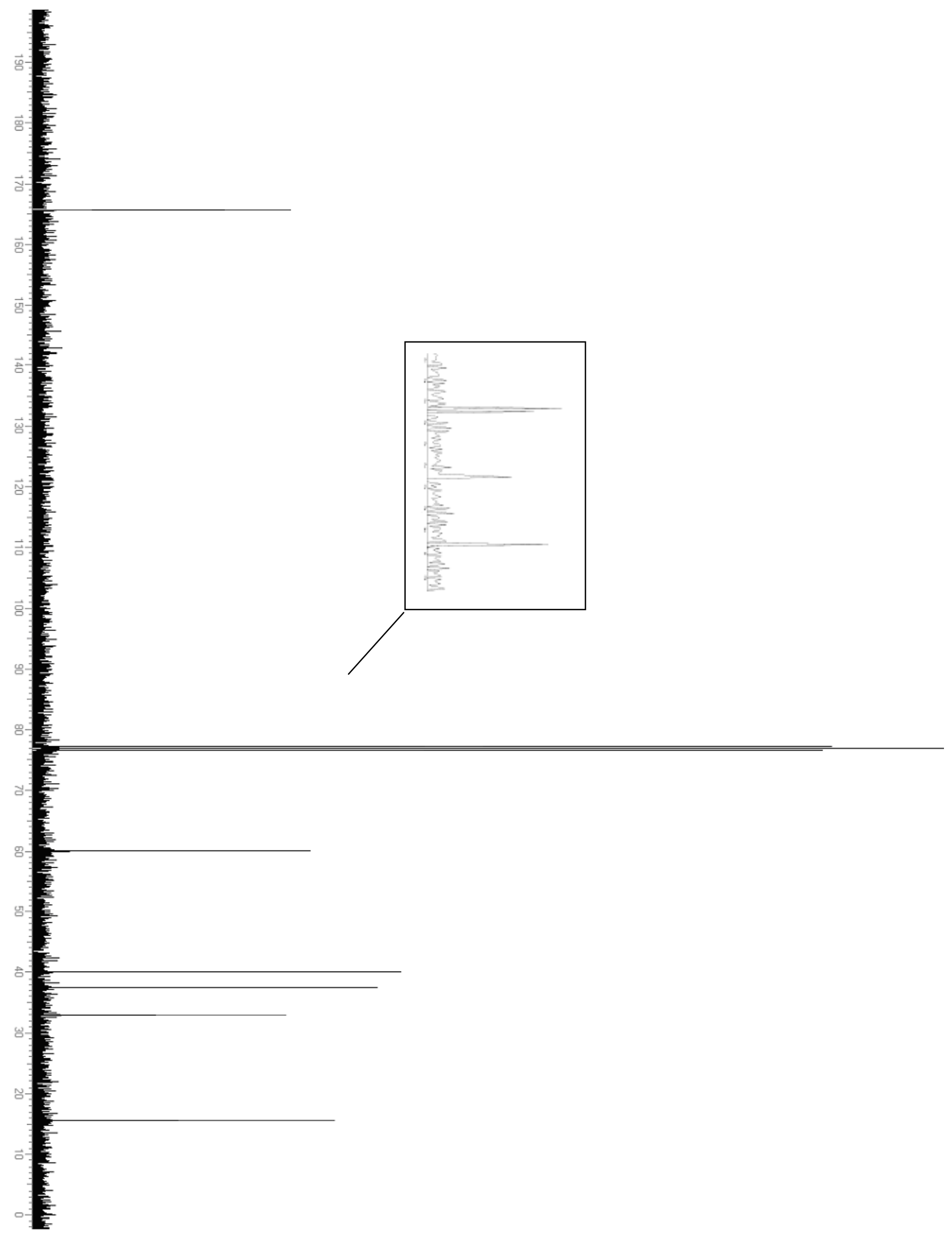


${ }^{1}$ Still, W. C.; Kahn, M.; Mitra, A., J. Org. Chem. , 1978, 43, 2923.

${ }^{2}$ C. Moody, B. A. Stakmann and D. W. Young, Tetrahedorn Lett., 1994, 35, 5485

${ }^{3}$ A. Ardá, C. Jiménez and J. Rodrígues, Tetrahedron Lett., 2004, 45, 1.

${ }^{4}$ J. Yoshimura, H. Nakumura and K. Matsinuri, Bull. Chem. Soc. Japan, 1975, 48, 605

${ }^{5}$ J-Yu Su, Y-U. Zhong, L-Mei Zheng, S. Wei, Qi-Wen Wong, T. C. W. Mak and Z-Y. Zhou, J. Nat. Prod., 1993, $56,637$. 